NB: This is the author's pre-print version. For citing this paper, please refer to the published version in Kronoscope 20/1 https://doi.org/10.1163/1568524112341454

\title{
DIPLOMATIC DEVICES: THE SOCIAL LIVES OF FOREIGN TIMEPIECES IN LATE SIXTEENTH- AND EARLY SEVENTEENTH- CENTURY JAPAN
}

\section{Introduction}

"In our monasteries we have clocks made of iron; the Japanese have only water clocks"

(Luis Frois, Treatise on Striking Contrasts in the Customs of Europe and Japan, 1585)

One of several hundred pithy antithetical couplets that sought to portray Japan in all of its cultural difference, this observation was included by the Portuguese Jesuit Luis Frois in his Treatise on Striking Contrasts in the Customs of Europe and Japan (Tratado em que se contem muito susinta e abreviadamente algumas contradisões e diferenças de custumes antre a gente de Europa e esta provincia de Japaõ, 1585), which was probably written as a didactic text for newly arrived missionaries in Japan. ${ }^{1}$ From a historical vantage point, however, this simple summation of Japanese time practices fails to pass scrutiny: not only were water clocks by no means the only method of time measurement in a country that could boast a centuries-long tradition of incense clocks, ${ }^{2}$ but the "clocks of iron" that Frois places as the (implicitly superior) European counterpart to the Japanese "other" had already begun to arrive on Japan's shores at the time of writing - albeit in very limited numbers. Yet it is clear that Frois' perceived "contrast" runs deeper than the material objects themselves. European-

\footnotetext{
${ }^{1}$ Daniel T. Reff, Richard K. Danford, and Robin Gill, eds., The First European Description of Japan, 1585: A Critical English-language Edition of Striking Contrasts in the Customs of Europe and Japan by Luis Frois (London: Routledge, 2014). The translation is taken from ibid., 117.

${ }^{2}$ On the history and use of incense clocks in East Asia, see Silvio A. Bedini, The Trail of Time. Time Measurement with Incense in East Asia (Cambridge: Cambridge University Press, 1994). On its usage in early modern Japan, particularly in the context of the pleasure quarters, see also Angelika Koch, "Nightless Cities: Timing the Pleasure Quarters in Early Modern Japan," Kronoscope 17, no. 1 (2017).
} 
style timepieces represented not merely a novel and different technology of time measurement in late sixteenth-century Japan but also an intercultural clash of ideas about time- and ultimately, as this article sets out to explore, a clash of different interests, meanings and perceptions in Japan and Europe.

The present paper does not aim to discuss early European clocks in Japan as a technology for time measurement or to trace their trajectory of scientific advancement, as has been the predominant discourse in histories of Japanese science and technology; ${ }^{3}$ in fact, imported mechanical clocks were to some extent "time-less" timepieces in Japan during this early period, as primary sources suggest that their time-keeping function was often secondary and sometimes non-existent due to the different hour system in use. ${ }^{4}$ Nor will this paper discuss these clocks as objets d'art, although they certainly had artistic and decorative value - an aspect which remains elusive as few of these timepieces remain in existence as actual, material objects. Instead, I am interested here in the social lives of European timepieces as a particular set of objects in late sixteenth- and early seventeenth-century Japan and in viewing them as actors that moved within the intercultural and interpersonal networks of exchange that existed primarily between Europe and Japan, but also significantly within East Asia and Japan itself. Relying on Latour's definition of actors as "any thing that [modifies] a state of affairs by making a difference," ${ }^{5}$ we shall see that European timepieces indeed "made a difference" in a variety of ways - enabling connections, affording opportunities and creating relationships of trade, diplomacy and of mutual obligation.

\footnotetext{
${ }^{3}$ See for example Hashimoto Manpei, Nihon no jikoku seido (Tōkyō: Hanawa Shobō, 2002), esp. 118-125; Yamaguchi Ryūji, Nihon no tokei: Tokugawa jidai no wadokei no kenkyū (Tōkyō: Nihon Hyōronsha, 1950), 157; in English also Yulia Frumer, Making Time: Astronomical Time Measurement in Tokugawa Japan (Chicago: University of Chicago Press, 2018), ch. 2.

${ }^{4}$ Frois commented on the discrepancies between the European and Japanese hour systems, pointing out the different number of hours per day and the unfamiliar counting system: "Our day and night come to a total of twenty-four hours; the Japanese have but six hours of day and six of night" and "We count the hours from one, two, three, up to twelve; the Japanese count them in this manner: six, five, four, nine, eight, seven, six etc." See Reff, Danford and Gill, First European Description, 118.

${ }^{5}$ Bruno Latour, Reassembling the Social: An Introduction to Actor-Network-Theory (Oxford: Clarendon, 2005), 71.
} 
This is not to imply that these early clocks were not also perceived as objets d'art or as a means of technological transfer by their contemporaries or that these meanings can always be neatly separated. Some of the devices that reached Japan had previously been owned by the European nobility and even by royalty, and their fine craftsmanship and costly materials made them literally fit for kings. Similarly, there is no doubt that the arrival of these mechanical clocks in the mid-sixteenth century had a lasting and far-reaching technological impact. According to the standard narrative that appears in many a history of clocks and time measurement, the Japanese in the early seventeenth century began to adapt the newly imported technology of European mechanical clocks by devising their own "Japanese-style" timepieces (retrospectively termed wadokei) and gradually developed a number of idiosyncratic technological solutions that allowed them to accommodate their own seasonal time system of variable hours. ${ }^{6}$

Yet discussing these early clocks merely as technological catalysts for Japanese-style clocks and distant predecessors of modern Japanese time consciousness ${ }^{7}$ ignores a whole spectrum of meanings assumed by European timepieces in contemporary records: as global gifts, as diplomatic tools, and as a commodity constituting power relations on both the local and transnational stage. The cogwheels and bolts, the time mechanism, and the decorative casing all formed an important part of the materiality of these clocks, but ultimately they were polysemous objects with social meanings and value that cannot be reduced to the sum of their technological parts and their function as timekeepers alone. It is as such that the present paper will explore them, arguing that these micro-histories of individual encounters and exchanges can ultimately contribute to our understanding of the history of time - and

\footnotetext{
${ }^{6}$ These included separate, changeable clock faces for different seasons, moveable hour markers on clock faces and foliots with adjustable weights for regulating the speed. For an overview, see Frumer, Making Time, Ch. 2.

${ }^{7}$ See fn. 4. For the association of clocks with punctuality, see Takehiko Hashimoto, "Japanese Clocks and the History of Punctuality in Modern Japan,” East Asian Science, Technology and Society 2, no. 1 (2008): 123-133.
} 
may even shed light on the question of why Japan's history followed such a different trajectory from European societies in the wake of the introduction of mechanical clocks.

What I define as "early European timepieces" in Japan for the purposes of the present paper covers roughly the second half of the sixteenth and the early part of the seventeenth centuries. Our point of departure is the first recorded appearance of a European mechanical clock in Japan in 1551 at the hands of Jesuit Francis Xavier, and the end point the arrival of the oldest extant mechanical clock, gifted to the former shogun, Tokugawa Ieyasu, in 1611 and preserved today in the Kunōzan Tōshōgū Shrine in Shizuoka Prefecture. The choice of this period of sixty or so years is based not only on the symmetry of two "firsts" in the history of Japanese timepieces but also on a certain socio-cultural logic.

The late sixteenth and early seventeenth centuries represented an age of encounter for Japan when Japanese networks of trade and diplomacy were expanding rapidly and first contact was made with European nations. ${ }^{8}$ In the wake of the first wave of globalization during the 1500 s that witnessed the influx of European nations into maritime Asia, ${ }^{9}$ the Portuguese and Spanish arrived in the islands of Japan in the mid-sixteenth century, followed by the Dutch and English a few decades later. Attracted by the prospect of trade in exotic goods and the riches of the region's gold and silver mines - along with countless new souls requiring salvation for the greater glory of God — merchants, missionaries, adventurers, and diplomats ventured across the ocean, seeking access to pre-existing transnational commercial networks in Asia for trade and local communities for proselytizing.

Among the first foreigners to set foot in Japan were the "Southern Barbarian (nanban)" Jesuits from Portugal, Spain, and Italy, who became important actors in the transmission of

\footnotetext{
${ }^{8}$ Ronald Toby, Engaging the Other. "Japan” and its Alter Egos, 1550-1850 (Leiden: Brill, 2019).

${ }^{9}$ For a world history perspective on the Eurasian exchange in maritime Asia and its place in the "first global age", see Geoffrey C. Gunn, First Globalization: The Eurasian Exchange, 1500 to 1800 (Lanham, Md.: Rowman \& Littlefield, 2003).
} 
the earliest European timepieces to Japan. ${ }^{10}$ Through their accounts and letters, many of which were widely popularized in commercial print beyond the confines of the Society of Jesus, Europeans were given their first glimpse of the far-away, fabled Japanese archipelago. Conversely, the Jesuits were important intercultural mediators for Japan and other Asian countries, introducing new objects and knowledge in their quest to gain favour and ultimately win over local elites and the population at large to their religious beliefs. It is therefore unsurprising that most of the accounts that have come down to us today of early European clocks in Japan are from Jesuit sources. These form the backbone of the present analysis but, wherever possible, they are supplemented by documentary evidence from European traders, diplomats, aristocrats, and others involved in bringing Western timepieces to Japan, and by the comparatively sparse evidence that has survived in Japanese sources. The fact that the Japanese perspective on events is often mediated by the dominant European (Christian) gaze is problematic but also unavoidable, as such sources remain our main point of access to the matter at hand.

Japan's opening up to the world, however, proved to be a relatively brief interlude before the country embarked on an increasingly exclusionist course. ${ }^{11}$ The final expulsion of the Southern Barbarians in 1639 due to their missionary activities signalled the end of Japan's "Christian century," following which the Dutch were the only European nation to be granted relations with Japan. The Dutch continued to bring European-imported clocks to Japan

\footnotetext{
${ }^{10}$ There is a burgeoning literature on the Jesuit enterprise in Japan, but for some overviews see Charles R. Boxer, The Christian Century in Japan, 1549-1650 (Berkeley: University of California Press, 1951); George Elison, Deus Destroyed: The Image of Christianity in Early Modern Japan (Cambridge, Mass.: Harvard University Council on East Asian Studies, 1988); Donald F. Lach, Asia in the Making of Europe, Volume I, Book 2 (Chicago: University of Chicago Press, 1965); Reinier Hesselink, The Dream of Christian Nagasaki: World Trade and the Clash of Cultures (Jefferson: McFarland \& Company, 2016).

${ }^{11}$ The notion that the country entered an era of "isolation" or "seclusion" (sakoku) has, however, been discarded, as although the Japanese government excluded the Spanish and Portuguese, it maintained diplomatic relations within East Asia (China, Korea) and with the Dutch. See Ronald Toby, State and Diplomacy in Early Modern Japan: Asia in the Development of the Tokugawa Bakufu (Princeton: Princeton University Press, 1984).
} 
throughout the Edo period, including some of the first pocket watches ${ }^{12}$ and, from the eighteenth century, all manner of pendulum clocks, table clocks, and musical clocks particularly coveted English timekeepers that represented the pinnacle of European clockmaking at the time. ${ }^{13}$ In fact, clocks remained one of the most sought-after commodities in the Dutch-Japanese trade, consistently appearing among the Dutch East India Company's official and private trade items, as well as in the orders placed by the Japanese to Dutch traders. ${ }^{14}$ Thus, it is clear that 1611 did not mark the end of exchanges of European-style timepieces; it did, however, represent the last (known) exchange in a series of Ibero-Japanese encounters involving clocks that began in the mid-sixteenth century and, as such, provides a suitable end point for our discussion.

In terms of Japan's domestic affairs, the period under consideration also roughly coincides with the unification of the country under three successive warlords: Oda Nobunaga (1534-1582), Toyotomi Hideyoshi (1537-1598) and Tokugawa Ieyasu (1543-1616), all of whom were central actors in Japan's encounter with European clocks. During this time, Japan emerged from a period of great fragmentation and military strife among competing local lords (daimyō), which ended with the final destruction of the Toyotomi family by the Tokugawa clan in 1615 and resulted in an era of "Great Peace" and centralized control under the Tokugawa shogunate (established in 1603). ${ }^{15}$ In this context, it is my contention in this

\footnotetext{
${ }^{12}$ The Dutch presented pocket watches (netsuke no jimeishō/tokei) to the shogun Tokugawa Iemitsu and his heir in 1647 (12/1 Shōhō 3) and a clock to Iemitsu in 1645 (12/28 Shōhō gannen). See Tokugawa jikki (maki 59) in Kokushi Taikei Kankōkai, eds., Kokushi taikei 40 (Tōkyō: Yoshikawa Kōbunkan, 1930), 379, 465.

${ }^{13}$ For a brief discussion of imported clocks during the Edo period, see Timon Screech, The Lens within the Heart. The Western Scientific Gaze and Popular Imagery in Later Edo Japan (Honolulu: University of Hawaii Press, 2002), 78-80, 130-131; on English timepieces, in particular, also Timon Screech, Edo no Igirisu netsu. Rondon bashi to Rondon dokei (Tōkyō: Kōdansha, 2006), 110-123.

${ }^{14}$ Martha Chaiklin, Cultural Commerce and Dutch Commercial Culture: The Influence of European Material Culture on Japan, 1700-1850 (Leiden: Research School CNWS Leiden University, 2003), 86-114.

${ }^{15}$ On the "three unifiers" and the socio-political fabric of the unification period, see for example Conrad Totman, Tokugawa Ieyasu: Shogun (San Francisco: Heian, 1983), Morgan Pitelka, Spectacular Accumulation: Material Culture, Tokugawa Ieyasu, and Samurai Sociability (Honolulu: University of Hawaii Press, 2016), Mary Elizabeth Berry, Hideyoshi (Cambridge, Mass.: Harvard University Press, 1982), Jeroen P. Lamers, Japonius Tyrannus: The Japanese Warlord Oda Nobunaga Reconsidered (Leiden: Hotei, 2000) and John Whitney Hall, Nagahara Keiji, and Yamamura Kozo, eds., Japan Before Tokugawa: Political Consolidation and Economic Growth, 1500-1650 (Princeton: Princeton University Press, 1987).
} 
paper that clocks played a part in establishing social links and power relations not only between European nations and Japan, but also within the socially volatile environment of the "Warring States" in Japan itself.

\title{
Ieyasu's Clocks: Timekeepers in Early Seventeenth-Century Japan
}

But what significance did "European timekeepers" have in Japan at that time? What kind of clocks did people exchange and own? One concrete example of clock ownership in the early seventeenth century that can help us begin to explore these questions can be found in a catalogue of the possessions of the first Tokugawa shogun, Ieyasu, that was drawn up shortly after his death in 1616 to facilitate the division of his assets. ${ }^{16}$ The section in the inventory of miscellaneous "small utensils" (komamono) reveals that Ieyasu, at the time of his death, owned the following timepieces:

\author{
“item: two sundials (hidokei) \\ item: one Chinese clock (kara no tokei) \\ item: one square clock (kata tokei) \\ item: two sand clocks (sunadokei)"17
}

The compilers of the catalogue have grouped this handful of items together, implicitly creating what would appear to be a common category of timekeepers. This suggests that there was an order of things in place that acknowledged a class of instruments, the purpose of

\footnotetext{
${ }^{16}$ Sunpu o-wakemono o-dōguchō (Record of utensils inherited from Sunpu Castle, 1616-1618). The items were mainly divided up between the three Tokugawa branch houses; the records preserved today are those of the Owari house, which list the objects in eleven ledgers in various categories, including clothing, medicine, and items of gold and silver (now owned by the Tokugawa Art Museum in Nagoya). A transcription of these documents can be found in (Tōkyō Teikoku Daigaku Bungaku-bu) Shiryō Hensangakari, eds., Dai Nihon shiryō 12/24 (Tōkyō: Teikoku Daigaku, 1923), 652-739, 756-865. The second extant set is from the Mito branch house and is now in the possession of the Tokugawa Museum in Mito.

${ }^{17}$ Shiryō Hensan, Dai Nihon shiryō 12/24, 796-797.
} 
which was to measure time - regardless of their various mechanisms. ${ }^{18}$ It is difficult to determine with certainty the exact nature of these instruments, but one can reasonably argue that the list contains three types of timepiece: sundials, hourglasses and mechanical clocks, provided one takes the general term "clock" (tokei) to signify "mechanical clock.",19

If so, all of these timepieces, both mechanical and non-mechanical, would have likely been viewed as unfamiliar and novel objects in Ieyasu's time - which may help to explain why their ownership was sought-after in the first place. The use of hourglasses had been widespread in Europe from the fourteenth century onwards, both for private and official use ${ }^{20}$ in Japan, however, techniques of glass production were unknown before the arrival of the "Southern Barbarians," hence the very material of the items in and of itself was a foreignimported curiosity that was popular throughout the early modern period. ${ }^{21}$ In fact, early seventeenth-century letters from the English navigator and shogunal advisor William Adams, in which he repeatedly asks his superiors in London to send "running glasses," indicate the demand for such non-mechanical timekeepers. ${ }^{22}$ Jesuit sources also support such a view, mentioning gifts of hourglasses to the Japanese warrior elite and requests for such items from

\footnotetext{
${ }^{18}$ It may also reflect the way these items were stored and managed prior to their distribution; in the case of certain sections of the catalogue (particularly clothing and documents) it is clear that the catalogue was compiled by going through Ieyasu's belongings box by box.

${ }^{19}$ It should be noted that the term tokei in premodern usage was also used for other types of timepieces, particularly sundials and sand-driven clocks; yet given that these are listed separately here with their own specific terms, the interpretation of tokei as 'mechanical clock' is most likely. Water clocks were normally termed rōkoku and incense clocks kōban, rather than tokei. Sunadokei is also a somewhat ambiguous term, as it could designate both hourglasses and clepsydra-like pieces that used sand instead of water. See Hashimoto, Nihon no jikoku, 211-213. Yet references to such sand-driven clepsydrae as instruments for time measurement appear to be exceedingly rare in Japan before ca. 1700, which is why the interpretation as hourglasses is more likely here, particularly given that they were not uncommon import items at the time.

${ }^{20}$ These included nautical contexts, town meetings, and the timing of work breaks. See Gerhard Dohrn-van Rossum, History of the Hour: Clocks and Modern Temporal Orders (Chicago: University of Chicago Press, 1996), 117-118 and Gerhard Dohrn-van Rossum, "Time" in The Oxford Handbook of Early Modern European History, 1350-1750. Volume 1, ed. Hamish Scott (Oxford: Oxford University Press, 2015), 149-153.

${ }^{21}$ Chaiklin, Cultural Commerce, 115-148 and Screech, Lens Within, 133-165.

${ }^{22}$ William Adams' letters dated 1 December 1613 in Anthony Farrington, The English Factory in Japan, 16131623 (London: British Library, 1991), 108, 112. Adams requested these hourglasses for navigational purposes, as they were used to determine the speed and distance traveled of the ship.
} 
Japanese converts. ${ }^{23}$ Frois, for example, records that on his visit to Oda Nobunaga to thank him for granting permission to preach and move freely in the capital, he presented the warlord with the rather unusual combination of "an exotic bird's (ema) egg and an hourglass, for want of anything else." 24

Portable sundials were likewise imported to East Asia; the diary of Richard Cocks, the head of the relatively short-lived English trading post (1613-1623) in Japan, recorded, for example, a gift of "two ivory sundials, compass-like" to the "China captain" upon hope of trade with the continent. ${ }^{25}$ This is somewhat surprising, given that sundials are one of the oldest forms of time measurement, but it appears they were not particularly widespread in pre-Edo Japan beyond astronomical uses - a peculiarity that Japan shared to some extent with China. ${ }^{26}$ In court astronomy and government offices, water clocks were the other standard method for time measurement, while monastic communities usually relied on incense timekeepers to regulate their day. Significantly, the East Asian astronomical sundials were normally fixed in one place and were of an entirely different type (equinoctial) from

\footnotetext{
${ }^{23}$ The Jesuit Luys Piñeyro, for example, mentions that a Christian court lady, exiled from the capital for her beliefs, wrote to the Jesuit padres to ask them to send her books detailing the lives of the apostles and martyrs, an image of a padre preaching, a bell, two candles and "an hourglass." The likely implication is that these items were required to celebrate mass. See Luys Piñeyro, Relacion del successo que tuvo nuestra santa fe en los Reynos del Iapon (Madrid: Alonso Martina de Balboa, 1617), 41. Similarly, in his history of the Japanese Church, Jean Crasset describes how Sebastian Kimura, the first Japanese to be ordained into the Jesuit priesthood, used an hourglass to time his sermons ("Il étoit si exact à faire ses oraisons, qu'il portoit toujours une horloge de sable pour en mesurer le temps."); see Jean Crasset, Histoire de l'Église du Japon (Paris: François Montalant, 1715), II 386. Such comments might suggest that hourglasses were used to time the liturgical hours of the Church for Christian converts in Japan; neither Crasset's nor Piñeyro's accounts, however, are based on their own firsthand experience in Japan.

${ }^{24}$ Frois letter dated June 1, 1569 in Cartas que os padres e irmãos da Companhia de Iesus escreuerão dos Reynos de Iapão \& China aos da mesma Companhia da India, \& Europa des do anno de 1549 até o de 1580 (Evora: Manoel de Lyra, 1598), I 262 r.

${ }^{25}$ Entry for 16 September 1615 in Richard Cocks, Diary of Richard Cocks, Cape-merchant in the English Factory in Japan 1615-1622, with Correspondence (London: Hakluyt Society, 1883), I 58.

${ }^{26}$ Overall there is very little documentary or material evidence to indicate the use of sundials in Japan before the Edo period. A report from a Korean official held captive in Japan from 1597 until 1600 indicates that a Japanese monk-astronomer in Kyoto built a 'clock that measured shadows'; yet significantly this was a 'shadow clock pedestal', rather than a portable sundial of the type that seems to have first appeared in Japan during the Edo period. For this Korean account, see JaHyun Kim Haboush and Kenneth R. Robinson, A Korean War Captive in Japan, 1597-1600: The Writings of Kang Hang (New York: Columbia University Press, 2013), 50.
} 
European-made pieces. ${ }^{27}$ The polymath Jesuit missionary Matteo Ricci, who introduced the Chinese to many aspects of Western calendrical and mathematical sciences in the late sixteenth and early seventeenth centuries, pointed out this fundamental discrepancy in his diary and constructed several sundials as gifts for nobles at the Ming court. ${ }^{28}$ One would suspect that the sundials listed among Ieyasu's possessions were of the portable imported type, given that they were categorised as komamono (small utensils) and included within his portable assets.

Thus, it is very likely that some or even all of the timepieces included among Ieyasu's assets held a connotation of the foreign at the time of his death - and by implication of the new, rare, and perhaps even the exotic. This was naturally also the case for the mechanical clocks that had first reached Japan during the previous half-century, mostly via European missionaries according to existing records. The fact that the list specifies a "Chinese clock" is hence worth noting, although it remains unclear whether this refers to China merely as the donor of a European-style clock or also to its place of production. ${ }^{29}$ In a similar vein, records suggest that in 1605 Ieyasu had a "Korean (chōsenkoku no) clock" repaired; ${ }^{30}$ this points towards the fact that European-style mechanical clocks were not only vehicles of cultural

\footnotetext{
${ }^{27}$ Chinese sundials consisted of a plate that was tilted in the plane of the equator and a gnomon that pointed towards the pole (equatorial or equinoctial type), while European portable sundials consisted of a plate with a gnomon that had to be adjusted with the aid of a compass. In China a type of portable sundial existed prior to the arrival of Europeans; see Joseph Needham, Science and Civilisation in China, Vol. 3. Mathematics and the Sciences of the Heavens and the Earth (Cambridge: Cambridge University Press, 1959), 310-312.

${ }^{28}$ See Ricci's letter in Pietro Tacchi Venturi, Opere Storiche del P. Matteo Ricci, S.I. (Macerata: Premiato Stab. Tip. F. Giorgetti, 1911), I 19. On Matteo Ricci's contributions to the history of clocks in China, see Joseph Needham, Wang Ling, and Derek J. Price, Heavenly Clockwork: The Great Astronomical Clocks of Medieval China (Cambridge: Cambridge University Press, 1986), 142-145; Catherine Pagani, Eastern Magnificence \& European Ingenuity: Clocks of Late Imperial China (Ann Arbor: University of Michigan Press, 2001), 2-3, 2630.

${ }^{29}$ If referring to its place of production, it may have been one of the mechanical clocks produced by the Jesuits in China. However, some doubt remains as to whether it refers to China/the Asian continent at all, given that "Chinese" was sometimes used as an umbrella term for "foreign"; yet the catalogue clearly records items in other categories as "Southern Barbarian (nanban)" and Dutch (Oranda), which makes this more general interpretation unlikely.

30 Fukada Masatsugu, Owarishi 1 (Tōkyō: Hakubunsha, 1898), 40. This record was, however, only retrospectively compiled in the nineteenth century (preface dated 1844) and some doubt has been cast on its historical accuracy in recent years. See Kawamoto Nobuo, "Nihon de no kikai tokei seisaku kaishi jiki no kōsatsu," Wadokei 47 (2015): 1-19. Kawamoto rejects the "Korean" provenance of the clock as unlikely, but considering Ieyasu's "Chinese clock," we cannot rule out the possibility.
} 
exchange between East and West, but also within East Asia, a fact that has so far been mostly overlooked and warrants further investigation. ${ }^{31}$

\section{Diplomatic Devices: The Jesuits and Early European Clocks in Japan}

How did the Japanese encounter European clocks as objects? If we consider the list of known interactions with these devices (see Appendix, Table 1) in the period under consideration, we can conclude that the actors involved in these exchanges were in general the Japanese ruling elite on the one hand, and Jesuit missionaries and foreign emissaries on the other. Needless to say, there were others who remained in the shadows and appear only rarely and cursorily in the historical record, including the mostly anonymous Japanese craftsmen who began to construct clocks based on the newly imported technology and the nameless masses of spectators who stood and watched as European timepieces were paraded as tributes to their rulers. We also need to be aware of a possible Jesuit slant in our picture of events due to the nature of available documentary evidence, most of which circulated within the highly efficient Eurasian information network of missionaries connecting those in the field with their powerbases back in Europe. While Japanese sources such as Ieyasu's catalogue strongly suggest some geographical movement of European and locally manufactured European-style clocks to Japan from the Asian continent, the details of such instances are currently lost to us, although they serve as a reminder that the narrative of early clocks in Japan was not necessarily purely Eurocentric. What has come down to us, however, is proof of a set of objects that traced global trajectories from nations such as Italy, Portugal, Spain, and possibly Germany, the leading centre of clock production in sixteenth-century Europe, with pedigrees

\footnotetext{
${ }^{31}$ Kondō Katsuyuki has, in fact, recently made the claim in his chronology of Japanese timepieces that the first clock was brought to Japan in 1539 by a Ming Chinese merchant; see Kondō Katsuyuki, "Edo tokei nenpyō kaiteiban," Wadokei 47 (2015): 30-35. Kondō does not cite his sources, but I believe this to be based on an erroneous interpretation of a passage from the seventeenth-century history Honchō tsūgan (1670); see the relevant entry for the seventh month of the year Tenbun 8 .
} 
of ownership that included prominent princes such as the Duke of Mantua and the Viceroy of New Spain (roughly present-day Mexico and Southwestern United States).

In this context, clocks were objects of intercultural and interpersonal exchange and actors in cultural networks that joined together nations and individuals, on both a local and transnational level. As they moved within these networks, what meanings, emotive associations, and identities did these early clocks assume? From the viewpoint of foreigners in Japan, particularly the Jesuits, these clocks first and foremost represented a diplomatic tool, as is clear from the example of the first known mechanical clock to reach Japan, which was presented by the Jesuit Francis Xavier to Ōuchi Yoshitaka, the daimyō of Yamaguchi in western Japan. In letters to his superiors and sponsors in Europe, Xavier and his fellow padre Cosme de Torres repeatedly describe such gifts as vital instruments in obtaining permission to preach in Japan. In January 1552 Xavier writes, for example, to the Society of Jesus in Rome that "the duke [=Ōuchi Yoshitaka] was much delighted by the letters and presents" sent by the Bishop and the Governor from India; in another letter, he profusely thanks the Captain of Malacca for the "gifts [he had provided] for the princes of this country." Instructing the Society on their further course of action in Japan, he recommends sending presents for "the king" and exhorts his fellow padres in Goa to prevail on the Governor to procure them. Xavier's tactics were successful in opening a pathway into Japan, since Ōuchi Yoshitaka, according to his report, was so taken with the presents that as a reward he welcomed them in his domain. ${ }^{32}$ Clocks thus became a diplomatic tool for the Jesuits in their efforts to gain a secure foothold in the country and they provided access to the highest

\footnotetext{
${ }^{32}$ See Cosme de Torres' letter of 29 September 1551 in Cartas, I 17 r; Xavier's letters in Georg Schurhammer and Josef Wicki, Epistolae S. Francisci Xaverii Aliaque Eius Scripta (Rome: Monumenta Historica Societatis Iesu, 1944), II 223; 226; 262-263. A detailed account of the gift exchange can be found in Georg Schurhammer, Francis Xavier: His Life, His Times. Vol.4. (Rome: Jesuit Historiographical Institute, 1982), 216-220.
} 
echelons of society - a role they went on to duplicate (albeit with greater long-term success) in China. ${ }^{33}$

Clocks opened the doors of the powerful and granted access to the world of political sociability at the time - often at close quarters. The Jesuit Luis Frois, for example, recounts an episode in 1569 when the shogun, Ashikaga Yoshiaki, refused him an audience after a number of daimyō had spoken against him. In response, a trusted Japanese friend advised Frois to bring his alarm clock (relogio do despertador), as this would guarantee him immediate access to the shogun to personally regulate the mechanism and explain its use - a tactic that indeed proved successful as he was "presently let in [to the shogun's presence]." 34 Just a few months earlier, Frois had demonstrated what was presumably the same alarm clock to Oda Nobunaga in Kyoto, who had sent for Frois for this express purpose and had invited him into the private inner sanctum of political power, where he informally conversed with Frois over tea "for two hours on the clock." 35 Such meetings were all the more fraught with meaning and vital to the Jesuit's project given the precarity of the missionaries' situation in the imperial capital; the Jesuits had, in fact, been expelled from Kyoto in 1565 following the murder of the shogun, Ashikaga Yoshiteru, and had only been granted permission by Nobunaga to return in 1568, a few months before Frois' audiences. By the second half of the sixteenth century, the Ashikaga shoguns had become mere pawns of powerful warlords who were competing for control over Kyoto. Frois would have been anxious to secure the Jesuit position in the capital and garner support from those in power, and his alarm clock appears to have functioned as an unlikely mediator for securing these ends.

\footnotetext{
${ }^{33}$ Unlike in Japan, clock making became an institutionalized part of Chinese court bureaucracy with the establishment of imperial clock workshops in the late seventeenth century enjoying court patronage, in which Jesuits worked alongside Chinese craftsmen. On the Jesuits' role in introducing clocks to China, see Pagani, Eastern Magnificence, Ch. 1 and the chapter on clocks in Ingrid Schuster, Faszination Ostasien. Zur kulturellen Interaktion Europa-Japan-China: Aufsätze aus drei Jahrzehnten. (Bern, Oxford: Peter Lang, 2007), 179-210.

${ }^{34}$ Frois' letter dated June 1, 1569 in Cartas, I 266 r.

${ }^{35}$ Ibid. I 262 r.
} 
In these encounters with the Japanese, it was the novelty of clockwork that was a great asset for the Jesuits. "Dominance by design," to apply historian Michael Adas's apposite phrase, that is, the use of Europe's technological prowess, ${ }^{36}$ became an important strategy for the Jesuits in their goal of bringing Japan into the Christian fold. In fact, both Jesuit and Japanese sources stress the novelty and wondrousness of these articles which "had never been seen in Japan and therefore garnered admiration," as Cosme de Torres notes in one of his letters. ${ }^{37}$ A contemporary Japanese account in the Ōuchi Yoshitakaki (Records of Ouchi Yoshitaka), which is generally believed to refer to the first mechanical clock in Japan, ${ }^{38}$ speaks of "five wondrous and valuable treasures" that the "Indians" had brought to their shores. ${ }^{39}$ These included "a mirror that could make old eyes see afresh" [i.e. spectacles], an instrument that "could play all the sounds of the thirteen-stringed koto without plucking any strings" [a harpsichord], "two mirrors that made one see far-away things very clearly" [possibly a telescope] and "a sounding bell that did not distinguish between the length of night and day in regulating the hours" [a mechanical clock]. ${ }^{40}$ The writer has clearly struggled to describe these objects and the absence of pre-existing terminology per se is a telling linguistic indicator of their novelty and originality in the Japanese context.

Technology and the will towards dominance by design are also a salient part of the report of the first Japanese embassy to Europe, the Tenshō Mission of 1584, compiled by the Jesuit priest Alessandro Valignano (De Missione legatorum Iaponensium ad Romanam

\footnotetext{
${ }^{36}$ Michael Adas, Dominance by Design: Technological Imperatives and America's Civilizing Mission (Cambridge, Mass. and London: Belknap Press of Harvard University Press, 2006). Adas uses the term in the context of US expansionism over the past four-hundred years, but it is just as applicable to other colonial enterprises that believed in their mandate to enlighten 'non-Western' people.

${ }^{37}$ Cartas, I $17 \mathrm{r}$.

${ }^{38}$ The identification of the Öuchi Yoshitakaki clock with Xavier's gifts to Yoshitaka relies mostly on the identity of actors and the similarity of the items recorded in the Japanese text and Jesuit letters. Xavier's fellow padre Cosme de Torres speaks of "a harpsichord and a clock" in a letter of 1551; later commentators such as Lucena included additional items such as Spanish wine, bread, and "other items previously unseen in Japan."

39 "India" (Jap. tenjiku) was used as a term to vaguely designate anywhere beyond the "Chinese" continent and "Indians" was one of the terms used to refer to the Jesuits in sixteenth-century Japan. See Toby, Engaging the Other, 75-76, 111.

${ }^{40}$ See Ōuchi Yoshitakaki, in Gunsho ruijū (gassenbu 26), Zoku Gunsho Ruijū Kanseikai, eds., Gunsho Ruijū 21 (Tōkyō: Zoku Gunsho Ruijū Kanseikai, 1957), 411.
} 
curiam, 1590). ${ }^{41}$ This diplomatic mission took four Japanese adolescent boys, relatives and retainers of prominent Japanese Christian daimyō, on a tour through Portugal, Spain, and Italy to the Holy See in Rome. It was conceived by Valignano essentially as a promotional tour aimed at raising awareness and support for the Jesuit mission to Japan in Europe on the one hand, and at dispelling Japanese suspicions of Europe and the Portuguese on the other. It took the form of a (strictly controlled) demonstration of the magnificence of European courts, the wealth of its cities, and, above all, the splendour and authority of the Church. Mechanical and engineering marvels such as the aqueduct at Toledo, the glass manufacturers of Murano, and the Pratolino fountains near Florence played a significant part in this carefully constructed image of Europe, asserting the West as a place of boundless power and unrivalled technological development.

Clocks featured prominently in this stratagem ${ }^{42}$ the report, for example, provides a detailed description of the public clock in Venice, built by Gian Paolo Rainieri in the late fifteenth century, and ends with the Japanese emissaries duly expressing their awe at its ingenuity, exclaiming how "admirable indeed are the works of Europe, and the invention of this clock should rank as one of those most worthy of admiration." ${ }^{43}$ From the fact that Valignano had this report printed in Latin for use as a teaching tool for students at the Jesuit seminary in Japan, it is clear that this was the appropriate reaction expected from the Japanese in the face of European achievements. The text also served to make it abundantly clear that the Jesuits were the wellspring of such wondrous knowledge in Japan, as the clockwork mechanisms the emissaries observe in Europe resemble those "in the clocks which

\footnotetext{
${ }^{41}$ On this mission, see Michael Cooper, The Japanese Mission to Europe, 1582-1590: The Journey of Four Samurai Boys through Portugal, Spain and Italy (Folkestone: Global Oriental, 2005) and Derek Massarella, ed., Japanese Travellers in Sixteenth-century Europe: A Dialogue concerning the Mission of the Japanese Ambassadors to the Roman Curia (1590) (Farnham: Ashgate/Hakluyt Society, 2012), which provides an English translation and introduction to De Missione.

${ }^{42}$ Besides Rainieri's clock in Venice, the text also features the astrological clock in Toledo "which wonderfully imitates the movements of the celestial orbs" with the use of "eighteen hundred small spheres," so that "those who examine it are lost at this incredible spectacle." See Massarella, Japanese Travellers, 232.

${ }^{43}$ Ibid., 343.
} 
the fathers of the Society of Jesus bring to us [= the Japanese]." ${ }^{, 4}$ In this way, clocks acted as a tool to stimulate interest and build connections not only as material objects, but also served the same function in the narrative imagination.

Beside these "diplomatic" meanings, it is also highly likely that clocks fulfilled more routine time-keeping uses for the Jesuits in Japan around the turn of the sixteenth century. ${ }^{45}$ The workshop attached to the seminary in Arima, as Francisco Pasio proudly reported in his annual letter of 1601, produced not only paintings that were on a par with artworks in Europe but also organs, musical instruments, and "many mechanical clocks for our use (molti horologgi a ruote per uso di nostri)." ${ }^{46}$ The liturgical time of the church was one of the prime sites that developed a regime of time discipline in medieval Europe, requiring coordination of the various services during the course of the day, and Jesuit sources allude to the fact that some Japanese converts and priests used hourglasses for this purpose. ${ }^{47}$ According to the mission principles of Alessandro Valignano, who supervised the Jesuit activities in China and Japan, daily life at the Japanese seminary was also to be strictly regulated and his "daily order" provided an hour-by-hour schedule for young disciples ${ }^{48}$ - although we can only guess at the extent to which this was followed in practice. It is likely therefore that the "many mechanical clocks for our use" included such liturgical and everyday timing functions; yet the more symbolic agency of clocks as mediators always loomed large for the missionaries. Ultimately, Pasio thus tellingly concluded his brief remark on clocks with the comment that these Jesuit-

\footnotetext{
${ }^{44}$ Ibid., 266.

${ }^{45}$ Pagani and others have furthermore pointed out the theological significance of clockwork in contemporary perceptions as an expression of the creator's ordering of the universe; see Pagani, Eastern Magnificence, 34. While this aspect may have appealed to the Jesuits, there is currently no evidence that they conceptualized and used clocks as theological tools in their encounters with the Japanese. Lucena, however, draws on this trope in his early biography of Francis Xavier, remarking how the Japanese must have grasped God's providence and wisdom from their observations of the movements of the clockwork that imitated those of the heavens. See Juan de Lucena, Historia da vida do padre Francisco de Xavier (Lisbon: Pedro Crasbeeck, 1600), 601.

${ }^{46}$ Francesco Pasio, Lettera annua di Giappone scritta nel 1601 (Rome: Luigi Zannetti, 1603), 44.

${ }^{47}$ See fn. 24 above.

${ }^{48}$ For the original text and a German translation of this Regimento pera os seminarios de Japan (1580), see Josef Franz Schütte, Valignanos Missionsgrundsätze für Japan (Roma: Edizioni di Storia e Letteratura, 1951), I 432-440 and II 479-486.
} 
crafted devices "greatly pleased the Japanese and even the Daifusama [=Tokugawa Ieyasu] was entertained by them."

\section{The Power of Gifts and their Display: Clocks and the Japanese Ruling Elite}

If the Jesuits thus used clocks as a means to create connections and attract the Japanese to their cause - what did they represent for their Japanese recipients? This question has to be raised, particularly in view of the fundamental cultural clash inherent in these new-fangled devices, which apparently not only elicited a sense of wonderment, surprise, and delight at these European novelties, but also the feeling that they were complicated and impractical. Although "he very much desired it," Nobunaga refused Frois' offer of his alarm clock due to the fact that it was "laborious to regulate and would be wasted in his hands." Similarly, when asked by Frois if he would find the device useful, the shogun Yoshiaki replied that "he had never seen a more marvellous thing, but that it was lost on him, as he did not understand it." 49 Nobunaga and Yoshiaki may have been merely shying away from incurring the burden of a gift's reciprocity, but there was probably an element of truth in their pragmatic considerations. While the Jesuit reports implicitly put this rejection down to the European devices being too complex to handle and too technologically sophisticated for the Japanese, they in fact fail to capture the crux of the issue. As the Yoshitakaki succinctly puts it, the "sounding bell" of the Europeans "did not distinguish between the respective lengths of night and day in regulating the hours." In Japan, where the duration of the hours varied between the seasons and between night and day, this fixed hour-system of European clocks clearly posed a fundamental barrier to the practical usefulness of such imported devices.

This does not imply that they held no value for the Japanese; for as the Jesuits and their clocks entered the circles of sociability and the local culture of gift exchange that

\footnotetext{
${ }^{49}$ Cartas, I 262 r, 266 r.
} 
prevailed in Japan, timepieces assumed meaning within this context. Indeed the majority of the timepieces that appear in records of this period circulated as presents for the Japanese political elite. Clocks were, of course, also supremely successful European diplomatic offerings at the Chinese court and not uncommon princely gifts in Europe at the time. ${ }^{50}$ Gugliemo Gonzaga (1538-1587), the Duke of Mantua, for example, presented a clock to Margherita Farnesein 1581, together with a pearl-studded box and a bottle of perfume; he also bestowed "four small striking clock-watches to be worn around the neck" (quattro horiuoli che sonano, piccioli, per portar al collo) on the four Japanese members of the Tenshō Mission in $1585 .{ }^{51}$ In this sense, the Japanese elite can be said to have entered the global circuit of gift exchanges and its circulation of fashionable luxury goods, which by the late sixteenth century had come to include clocks amongst its prized items.

Gift-giving was in fact a standard practice in premodern Asian trade and was considered a necessary expense for business by Europeans. ${ }^{52}$ In Japanese society it was already a long-established institution pivotal to social interactions: contemporary Japanese diaries and those of foreign visitors alike attest to a constant stream of offerings arriving almost daily at elite households as seasonal gifts and as tokens of friendship, gratitude, and obligation. ${ }^{53}$ Joao Rodrigues, a Jesuit padre and observer of Japanese mores, describes how it was "customary in Japan on the occasion of visits or at other times to send gifts of cloth, robes, silk, gold, silver and many sorts of food," which were often delivered by the donor's

\footnotetext{
${ }^{50}$ On clocks as noble gifts in China, see Pagani, Eastern Magnificence, particularly 70-75 and Klaus Maurice, "Propogatio fidei per scientias: Jesuit Gifts to the Chinese Court," in The Clockwork Universe: German Clocks and Automata, 1550-1650, eds. Klaus Maurice and Otto Mayr (Washington D.C.: Smithsonian, 1980), 27-36. On clocks as courtly gifts in the sixteenth century, for example between the Austrian Habsburg and Turkish empires, see Gottfried Mraz, "The Role of Clocks in the Imperial Honoraria for the Turks," in ibid., 37-48.

${ }^{51}$ See the letter of 3 April 1581 (ID 867) and the report dated July 1585 (ID 6933) in the Archivio corrispondenza Gonzaga 1563-1630 database. The Gonzaga documents describe these four clocks simply as "clocks (orologi)"; the more detailed information above comes from Guido Gualtieri, Relationi della venuta degli ambasciatori giaponesi (Rome: Francesco Zannetti, 1586), 135.

${ }^{52}$ Boxer, Christian Century, 110; Chaiklin, Cultural Commerce, ch. 3.

${ }^{53}$ For examples of gift-giving, its frequency and motivation in the imperial household in the late fifteenth and sixteenth centuries, see Lee Butler,"Gifts for the Emperor: Signposts of Continuity and Change in Japan's Fifteenth and Sixteenth Centuries," in Mediated by Gifts: Politics and Society in Japan, 1350-1850, ed. Martha Chaiklin (Leiden: Brill, 2017), 48-81.
} 
messengers, to be duly recorded and then ceremonially presented to the recipient. ${ }^{54}$ The English encountered this Japanese penchant for gifts in their efforts to establish trade relations in the early seventeenth century, with William Adams alerting the East India Company that "the charges [for trade] in Japan are not great," but would by necessity include "a present for the Emperour and a present for the Kinge, and 2 or 3 pressents for the secretaries." 55

Naturally, such gifts were calculative in outlook as they entailed an inherent obligation to make some form of repayment, which blurred the lines between gift and commodity. ${ }^{56}$ According to Frois, everyone who had business with Nobunaga, be it townsman, monk or samurai, showered him with presents in order to gain permissions and garner favour - a practice that also existed at the imperial court. ${ }^{57}$ Within the context of this highly developed gift culture, objects held great power and agency in creating interpersonal relations and upholding the social and political order - and it was precisely as such that early clocks held value for the Japanese.

To use Japanese historian Morgan Pitelka's apposite phrase, clocks became part of the "spectacular accumulation" of objects by the ruling elite that was such a salient feature of the time and an expression of the uneven power relations manifest in such gift-giving. ${ }^{58}$ Ownership of such objects and the ability to attract such rare and precious gifts from foreign visitors was a mark of prestige, an indicator of power, and a status symbol, particularly during the period of military unification of the country with its rapid shifts in power. It is important to note, however, that such exotic objects also appear as gifts from vassals, subjects,

\footnotetext{
${ }^{54}$ Translated in Michael Cooper, This Island of Japon: Joao Rodrigues' Account of Sixteenth-Century Japan (Tōkyō: Kodansha International, 1973), 91-92, 166-167.

${ }^{55}$ William Adams' letter dated 12 January 1613 in Farrington, English Factory, I 77.

${ }^{56}$ On the relationship between gifts and commodities, see Arjun Appadurai, "Introduction: Commodities and the Politics of Value", in The Social Life of Things: Commodities in Cultural Perspective, ed. Arjun Appadurai (Cambridge: Cambridge University Press, 1986), 13.

${ }^{57}$ Frois' letter dated 1 June 1569 in Cartas, I 261 v. Gift-giving at the imperial court could involve imperial favours such as the bestowal of court ranks; see Butler, "Gifts."

${ }^{58}$ Pitelka, Spectacular Accumulation. Pitelka develops this idea in relation to meibutsu, well-known Japanese and Chinese objects, ownership of which was coveted, particularly for the tea ceremony.
} 
and peers; for once clocks arrived in Japan, they became objects of desire that moved not only transnationally, but also regionally and locally.

This becomes, for example, clear from Frois' abovementioned report on how the Japanese competed with each other in sending presents to the warlord Oda Nobunaga, taking advantage of his well-known foible for European exotic items in order to obtain his "vermillion seal (goshuin)" of approval. Frois goes on to describe the foreign origin of many of these gifts: "I was astounded with the amount of things [from India and Portugal] that he was presented with; I cannot imagine how these goods arrive at such a far-flung place in such large quantities. [...]. There are so many of these gifts that Nobunaga can fill twelve, fifteen trunks with them within three or four months." ${ }^{, 59}$ Among the (possibly hyperbolic) trunkloads of foreign presents in circulation, Frois lists sundials and hourglasses, alongside rarities such as leather from Cordoba and glassware. This report suggests that timepieces were also used by the Japanese, who harnessed the power of these objects to vie for the favour of those in authority. At the time that Frois was writing, Nobunaga had in fact just succeeded in entering the capital Kyoto and had installed a new shogun, but the warlord's authority was such that petitioners generally sought to gain both permission from the shogun and Nobunaga's vermilion seal ${ }^{60}$ - which made these gifts an expression of hierarchical social bonds and of Nobunaga's particular position of power.

At the same time, authority and influence could also be demonstrated by the ability to demand possession of such prized items as caught one's eye. An early seventeenth-century Japanese chronicle, for example, records an exchange between the retired shogun, Ieyasu, who had abdicated in favour of his son Hidetada and taken up residence at Sunpu Castle (in present-day Shizuoka Prefecture), and Naruse Masatake (?-1615), one of Hidetada's vassals. Masatake arrived in Sunpu to report on the progress of the construction of Edo Castle, but the

\footnotetext{
${ }^{59}$ Cartas, I 261 v.

${ }^{60}$ Hall, Japan before Tokugawa, 153.
} 
record of his visit closes with the apparently unrelated note that he was ordered "to present a clock without weights to the shogunate." ${ }^{61}$ It thus appears that Ieyasu actively sought out ownership of a particular clock, although the reason for this is unclear. Some indication may be provided by the comment that it was a "striking clock without weights (omori nashi jimeishō)"; early Japanese clocks were generally weight-driven, which is why the request for a timekeeper "without weights" points towards an imported device that was more technologically advanced, compact, and spring-driven.

Gift-giving, however, was not merely about the power of ownership; part of its value for the Japanese ruling elite also derived from the display and spectacle surrounding it. When the Jesuit-led Tenshō Mission returned from Europe in 1591 and presented Toyotomi Hideyoshi with presents (including at least one clock), the gifts were paraded in a procession of great pomp designed to impress onlookers with the ruler's power to command foreign riches and respect. ${ }^{62}$ As historian Ronald Toby has noted, such parades served an important ideological function by demonstrating the ruler's majesty, authority, and legitimacy ${ }^{63}-$ and gifts, including clocks, formed part of this.

This particular parade was officially construed as an embassy on behalf of the Viceroy of Portuguese India, as Hideyoshi wished to distance himself from the Jesuits and purge the procession of any religious meaning following his ban on all missionary activity in $1587 .{ }^{64} \mathrm{It}$ must have been a splendid sight to behold: the Jesuit padres, Portuguese merchants from Nagasaki as foreign "emissaries" on horseback in luxurious exotic clothing, the four Japanese

\footnotetext{
${ }^{61}$ The Tokugawa jikki cites this event twice with two different dates (based on two different documents), once on the $4^{\text {th }}$ day of the $6^{\text {th }}$ month of Keichō 17 (1612) and once in Keichō 19 (1614). See Kokushi taikei kankōkai, eds., Kokushi taikei 40, 588, 666.

${ }^{62}$ This event was reported in great detail in Frois' annual letter from Japan of 1592 and my description is based on Lettera del Giappone de gli anni 1591 et 1592 (Milano: Stampa del quon. Pacifico Pontio, 1595), 10-48; later accounts can also be found in Crasset, Histoire and in François Solier, Histoire ecclésiastique des isles et royaumes du Japon (Paris: Sebastien Cramoisy, 1627).

${ }_{63}^{63}$ Toby, State and Diplomacy, 64-76.

${ }^{64}$ This initial ban on missionary activity was only partially enforced. While some of the Jesuit establishments were destroyed, the missionaries, rather than leaving the country as ordered, went underground and were tacitly tolerated by Hideyoshi as necessary mediators for Portuguese trade.
} 
youths attired in their European finery, and an Arabian horse with a turbaned Indian groom in the vanguard of the procession, all coming to pay their respects. Bearing lavish gifts and an official letter from the Viceroy congratulating him on his conquest of the Japanese realm, they visibly performed Hideyoshi's political legitimacy as lord of the recently unified realm, both to the masses of curious onlookers lining the streets and the nobles of the land gathered in the audience hall. Having only recently succeeded in crushing the last domestic stronghold of resistance at the siege of Odawara the previous year and already setting his mind on the lofty goal of invading Ming China, Hideyoshi was, according to Jesuit sources, pleased with this show of foreign recognition, which undoubtedly bolstered perceptions of his authority. The clock that Valignano gifted to Hideyoshi (possibly the one he had received from the Archbishop of Evora in Portugal ${ }^{65}$ was singled out for special attention the following day, when Hideyoshi granted an audience to the Jesuits and the Japanese youths in order for them to demonstrate how to use it.

A somewhat different example of display occurred in 1606, when Joao Rodrigues presented Ieyasu at Fushimi Castle with a "striking clock that marked the course of the sun and moon." ${ }^{66}$ Ieyasu was reportedly highly pleased with such a rare and precious present and took the unusual measure of having the clock installed on a tower of the castle, so that "people could duly admire it." The Jesuit source interprets this act as a demonstrative display of cultural power aimed at eliciting awe and admiration from spectators both within and without the castle walls vis-à-vis the clock and, by extension, its owner. We may also speculate as to other symbolic reasons that may have contributed to this decision: Matteo Ricci had, for instance, installed a clock on the outside wall of his house that served as the

\footnotetext{
${ }^{65}$ See Valignano's letter to Teotonio of Braganza, the Archbishop of Evora dated 1 December 1587 in Cartas, II 232 v: "Among other things, I am much obliged to your Lordship for the rich and beautiful clock you sent me". ${ }^{66}$ This description of the clock can be found in Fernao Guerreiro, Relaçam annal das cousas que fizeram os padres da Companhia de Iesus nas partes da India Oriental (Lisbon: Pedro Crasbeeck, 1611), 111 and later in Solier, Histoire, II 409 and Crasset, Histoire, II 171.
} 
first "public" mechanical clock in China; ${ }^{67}$ in Japan, the Jesuit church in Nagasaki had erected a bell tower three years previously in 1603; and churches in Japan were graced with clocks designed by the Jesuit padre and artist Giovanni Nicolao (Cola) that reportedly showed astronomical and calendrical details - perhaps not unlike the clock depicted in a contemporary Western-style screen produced in Japan (see Fig. 1). ${ }^{68}$ Did Ieyasu hence take inspiration from Jesuit precedent? Was he laying claim to a privilege that in Europe at the time was reserved for the Church and secular leaders? ${ }^{69}$

As Francisco Pasio's annual letter of 1601 reveals, Ieyasu was familiar with the Jesuit clocks and allegedly admired them greatly; it is also possible that this particular clock was in fact made by the Jesuits in Japan, rather than a European-imported piece, as some scholars have suggested. ${ }^{70}$ Be that as it may, it is safe to assume that the display of such a marvellous wonder was meant to enhance the prestige of the owner in the eyes of all who beheld it. Allegedly, the shogun Hidetada also had a clock "that would tell the hours" commissioned from the Jesuits in Nagasaki that he placed on a tower of Edo Castle the following year in $1607 .^{71}$

Significantly, such cursory references also indicate that by the dawn of the seventeenth century it was not only Jesuits who were manufacturing presumably Europeanstyle clocks in Japan but that Japanese craftsmen had begun to acquire these skills. The Jesuit

\footnotetext{
${ }^{67}$ Needham, Heavenly Clockwork, 143.

68 On this nanban-style folding screen, see Grace Vlam, "Kings and Heroes: Western-Style Painting in Momoyama Japan," Artibus Asiae 39, no.3/4 (1977): 220-250. For a brief introduction on Giovanni Nicolao (also known as Giovanni Cola), see Hesselink, Dream of Christian, 117-122. Nicolao has been termed an "Italian Renaissance man" due to his versatile artistic and scientific skill set, which included, according to a Jesuit letter, engraving, oil painting, mathematics and clock making. See Fernando García Gutiérrez, "Giovanni Cola S. J. (Nicolao). Un hombre del Renacimiento italiano trasplantado a Japón," Temas de estética y arte 25 (2011): 96-124.

${ }^{69}$ It is possible that this clock (and Hidetada's mentioned below) may have had a time-telling function. The issue of whether Jesuit-produced clocks in Japan were geared towards equal or unequal hours has so far not been raised in Japanese histories of timepieces. The European clock with verge and foliot escapement that became the prototype for Japanese clocks in the seventeenth century could accommodate unequal hours and some scholars argue that it was initially used in such a manner in medieval Europe.

${ }^{70} \mathrm{Such}$ an assumption is corroborated by the fact that the Jesuit-made clocks are repeatedly described in sources as "marking the course of sun and moon."

${ }^{71}$ Guerreiro, Relaçam 1607-8, 124. A Japanese translation of Guerreiro's text can be found in Matsuda Kiichi, ed., Jūroku-shichi-seiki Iezusukai Nihon hōkokushū (Kyōto-shi: Dōhōsha Shuppan, 1987), dai 1-ki.
} 
chronicler Fernão Guerreiro suggests, for example, in the annual reports he compiled that "some of the Japanese craftsmen are now already making their livelihood from this trade, which is sparing us [Jesuits] many hardships.” The beginnings of clock making in Japan are shrouded in relative obscurity, but the scarce evidence suggests that the Jesuits and highly skilled Japanese metal workers such as swordsmiths were at the vanguard of these developments. ${ }^{72}$ Although the bulk of Jesuit production must have been for ecclesiastic uses, the above passages clearly indicate some demand from the Japanese ruling elite, which accounts for Jesuit-built clocks being "given as presents to Japanese daimyo and also to Daifusama [=Tokugawa Ieyasu], who took a singular liking to them.",73
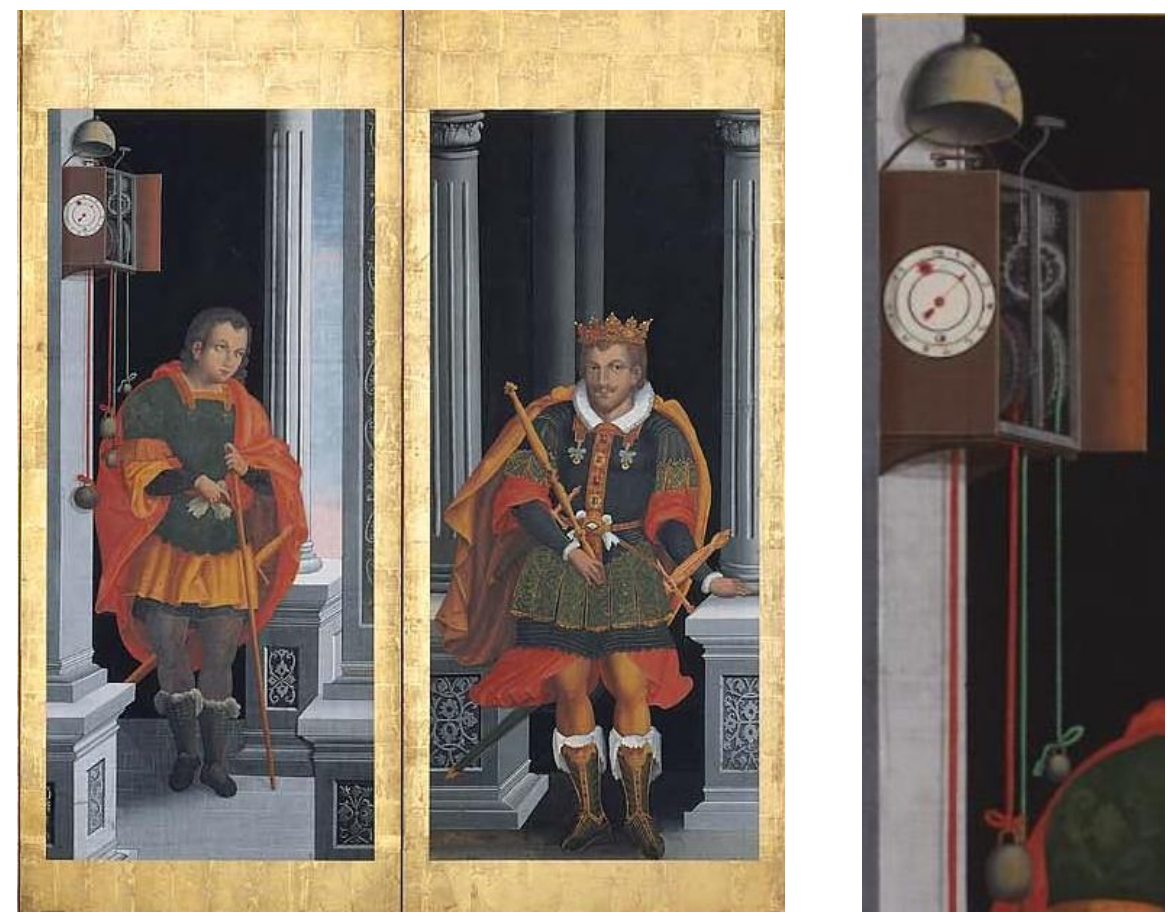

Fig. 1 Detail from an early seventeenth-century Japanese folding screen depicting a Western-style court setting with a wall clock that indicates the position of the sun and moon (European King and Members of His Court/Taisei $\overline{o k} \overline{\boldsymbol{o}}$ zu bȳ̄bu, Boston Museum of Fine Arts)

\footnotetext{
${ }^{72}$ For such a view, see Sawada Taira, Wadokei: Edo no haiteku gijutsu (Kyōto: Tankōsha, 1996). Hashimoto Manpei (Nihon no jikoku, 122) cites a seventeenth-century Japanese document that mentions a Japanese Christian "clocksmith" (tokei kaji), which suggests links between early clock making, Japanese metalworkers, and the Jesuit sphere of influence. For a rough chronology concerning the beginnings of clock production, see the Appendix.

${ }^{73}$ Fernão Guerreiro, Relaçam annal das cousas que fezeram os padres da Companhia de Iesus (Lisbon: Jorge Rodrigues, 1605), 9.
} 


\section{Ieyasu's Clock and the End of an Era}

The only timekeeper to remain today from these varied moments of exchange between Japan and the Southern Barbarians is a piece that has in recent years attracted attention in the media as "Ieyasu's Clock." ${ }^{74}$ It is preserved at the Kunōzan Tōshōgū Shrine, where Ieyasu was enshrined as a deity and his body was originally interred after his death at the nearby Sunpu Castle in $1616 .^{75}$ Standing $21 \mathrm{~cm}$ tall and executed in gilded brass with a dome design, this spring-driven table clock is the oldest extant mechanical timepiece in Japan; it bears a plaque that claims it was made in Madrid by the Flemish clockmaker Hans de Evalo in 1582, but recent X-ray analysis has revealed that it was in fact produced in Brussels in 1573 by another Flemish clockmaker, Nicolas van Troestenberch. ${ }^{76}$

Both of these craftsmen had close ties with the House of Habsburg that ruled over Flanders and the Low Countries at that time, which bears witness to the calibre of their work. Van Troestenberch was one of the Flemish clockmakers in the service of the Holy Roman Emperor Charles V, a monarch renowned for his fondness for clocks and astronomical instruments - to the extent that he took two clockmakers with him on his retirement to a Spanish monastery after his abdication. ${ }^{77}$ De Evalo, meanwhile, was a clockmaker at the

\footnotetext{
${ }^{74}$ Two books have recently appeared on the subject of Ieyasu's clock: one is by the head priest of the Kūnōzan Tōshōgū Shrine and the other is by the former vice-director of its museum. See Ochiai Hidekuni, Ieyasu-kō no tokei: yonhyakunen o koeta kiseki (Tōkyō: Heibonsha, 2013) and Mori Takeshi, Ieyasu no tokei toraiki (Shizuoka: Hagoromo Shuppan, 2017).

75 The exact date of when the clock was moved here is not known, but it appears in a 1668 inventory of Ieyasu's possessions held at the shrine (Kunōzan Tōshōgu on-dōgū chō).

${ }^{76}$ On the results of the 2013 inspection of the clock by European clock experts and the X-ray analysis, see Johan ten Hoeve and David Thompson, “A Flemish Clock at the Shogun's Shrine," Antiquarian Horology 35, no. 4 (2014): 1063-1076 and Sasaki Katsuhiro and Saitō Yō, "Kunōzan Tōshōgū ni hozon sarete iru 1581-nen Hansu de Ebaro-mei okidokei no kikō to yurai," Bulletin of the National Museum of Nature and Science. Series E, no. 39 (2016): 1-26.

${ }^{77}$ On Charles V's faible for clocks, see Cristiano Zanetti, Janello Torriani and the Spanish Empire: A Vitruvian Artisan at the Dawn of the Scientific Revolution (Leiden: Brill, 2017), ch. 4; on Flemish clockmakers and Charles V, Eddy Fraiture and Paul van Rompay, "Clock and Watchmaking in Belgium, 1300-1830," Antiquarian Horology 33, no. 1 (2011): 27-45. Van Troestenberch's father Jean had served as a clockmaker to
} 
court in Madrid to Charles's son, Philip II of Spain, from around 1580 - although significantly no record of "Ieyasu's clock" remains in the royal inventories from this period. ${ }^{78}$ The question of why and by whom the maker's name, place, and date of production of the clock were altered remains a mystery, although one might reasonably speculate that it was due to the increased prestige de Evalo enjoyed in Spain after entering the king's service. ${ }^{79}$

The clock's precise trajectory and the hands it passed through on its way from Flanders to Spain and finally overseas to the Spanish colonies in the New World remain unclear. It arrived in Japan as part of the consignment of gifts brought by Sebastiano Vizcaino and presented to Tokugawa Ieyasu in 1611 in the name of the Viceroy of New Spain as a token of his gratitude for the assistance provided to a Spanish ship wrecked off the coast of Japan two years earlier. ${ }^{80}$ Onboard this ill-fated vessel had been Rodrigo de Vivero, interim governor of the Philippines, who found words of high praise for the hospitality and honors accorded him in Japan during his eleven-month stay (from September 1609 until August 1610), including an audience with both Ieyasu and his son Hidetada. After Vivero's safe return to New Spain on a ship provided by Ieyasu, the explorer Vizcaino was charged with delivering a letter and gifts to Ieyasu, which included, according to Vivero's memoir,

\footnotetext{
Charles's father, Philip the Handsome. Only one other clock signed by Troestenberch is currently known to exist: a square table clock made in Brussels in 1566 that was last sold by Sotheby's in Paris in 2010.

${ }^{78}$ For the inventories drawn up of Philip II's estate in the early seventeenth century, which included 137 clocks and instruments, see F. J. Sánchez Cantón, ed., Inventarios reales. Bienes muebles que pertenecieron a Felipe II (Madrid: Real Academia de la Historia, 1956-1959), 309-332. On de Evalo, see Eduard Farré Olivé, "Vuelve a España el reloj de Hans de Evalo," Galería Antiquria 26, no. 276 (2008): 34-40 and Mori, Ieyasu no tokei. Two of de Evalo's clocks remain extant, one (d. 1583) of which is presently at the El Escorial Monastery near Madrid. ${ }^{79}$ Previous speculation has linked this alteration to the clock's departure for Japan, but I believe an earlier date is more likely. Although few details are known apart from its presence in New Spain in 1610, the clock had a long history before its arrival in Asia. By the time of its dispatch to Japan, Philip II had been dead for more than a decade and Hans de Evalo was no longer clockmaker to the court; it is also questionable as to whether the alteration would have enhanced the clock's prestige in the eyes of the Japanese as van Troestenberch was also a royal clockmaker.

${ }^{80}$ Its arrival is recorded in the list of gifts included in the Ikoku nikki, see Murakami Naojirō, ed., Ikoku o fuku shokanshū. Zōtei ikoku nikkishō (Tōkyō: Sunnansha, 1929), 69.
} 
"clocks, red wine and other trifles that the Emperor [Ieyasu] had requested from me" - a remark that once again suggests that Ieyasu actively sought to acquire clocks. ${ }^{81}$

Unlike its counterparts that are now irrevocably lost to us, this particular clock has had a long-lived and chequered biography over the centuries, during which it has slipped in and out of what Arjun Appadurai has termed a "commodity state." 82 Since the late nineteenth century it has appeared as a tourist attraction in postcards of the Kunōzan Shrine treasures, inspired clock-shaped cookies as a contemporary souvenir (Fig. 2), been registered as an "Important Cultural Property" (jīyō bunkazai) of Japan and most recently promoted in the media as a symbol of peace and friendship between nations, particularly Japan, Spain, and Mexico. ${ }^{83}$ In this way, the clock has constantly occupied new meanings and materialities across time - from a quasi-religious memento of the deified Ieyasu to a modern tourist commodity, an embodiment of the nation's cultural heritage and, particularly, a token of enduring goodwill between nations.

Yet despite such ongoing myth-making of the clock as a present-day diplomatic tool, in its historical context of the diplomatic relationship between Japan and Spain, the device was imbued with somewhat more ambiguous meanings, as becomes clear from the negotiations preceding the original gift exchange. Rather than a mere display of goodwill, Ieyasu was also bargaining for trade with the Spanish colonies in the Americas and technology exchange in the form of Spanish miners sent to help improve Japanese silver mines, while Vivero was seeking a substantial share of the profits of these mines for the Spanish, anchorage for their ships in Japanese harbors, the cessation of Japanese relations

\footnotetext{
${ }^{81}$ See Vivero's report titled Relación y noticias de el reino de Japón, manuscript copy held in the British Library, translated in Michael Cooper, An Unscheduled Visit: Rodrigo de Vivero in Japan, 1609-1610 (Tokyo: Asiatic Society of Japan, 2008).

${ }^{82}$ Appadurai, "Social Life", 13.

${ }^{83}$ This recently constructed idea of the clock as a token of friendship with Spain has attracted a number of highprofile visitors, including King Felipe and Queen Letizia of Spain in April 2017. A replica of the clock was gifted by the city of Shizuoka to Mexico in 2017.
} 
with the Dutch, and free rein for Jesuit missionary activities in Japan. ${ }^{84}$ None of these demands were ultimately met. ${ }^{85}$

To some extent, this episode represented a departure from earlier exchanges in that its main actors were not Catholic missionaries - although Spanish Franciscan friars based in Japan in fact still featured centrally as mediators, translators, and representatives. By the midnineteenth century, Japanese historians compiling a digest of foreign relations of the past three hundred years for the shogunate believed this to constitute the first appearance of a clock in their country - which suggests that by this time the Japanese documentary record had already fallen largely silent on earlier exchanges with the Jesuits. ${ }^{86}$ In reality, however, as has become clear in the present paper, these gifts to Ieyasu represented the last among several such exchanges between Japan and the Southern Barbarians stretching back several decades into the mid-sixteenth century.

\footnotetext{
${ }^{84}$ For Vivero's conditions and Ieyasu's response to them, see Cooper, Unscheduled Visit, also Archivo General de Indias (AGI) FILIPINAS, 193, N.3.

${ }^{85}$ For a detailed account of the ensuing, ultimately frustrated attempts to establish official trade relations between Japan and New Spain see Juan Gil, Hidalgos y samurais España y Japón en los siglos XVI y XVII. (Madrid: Alianza Editorial, 1991).

${ }^{86}$ Kokusho Kankōkai, eds., Tsūkō ichiran (Tōkyō: Kokusho Kankōkai, 1912), 50.
} 

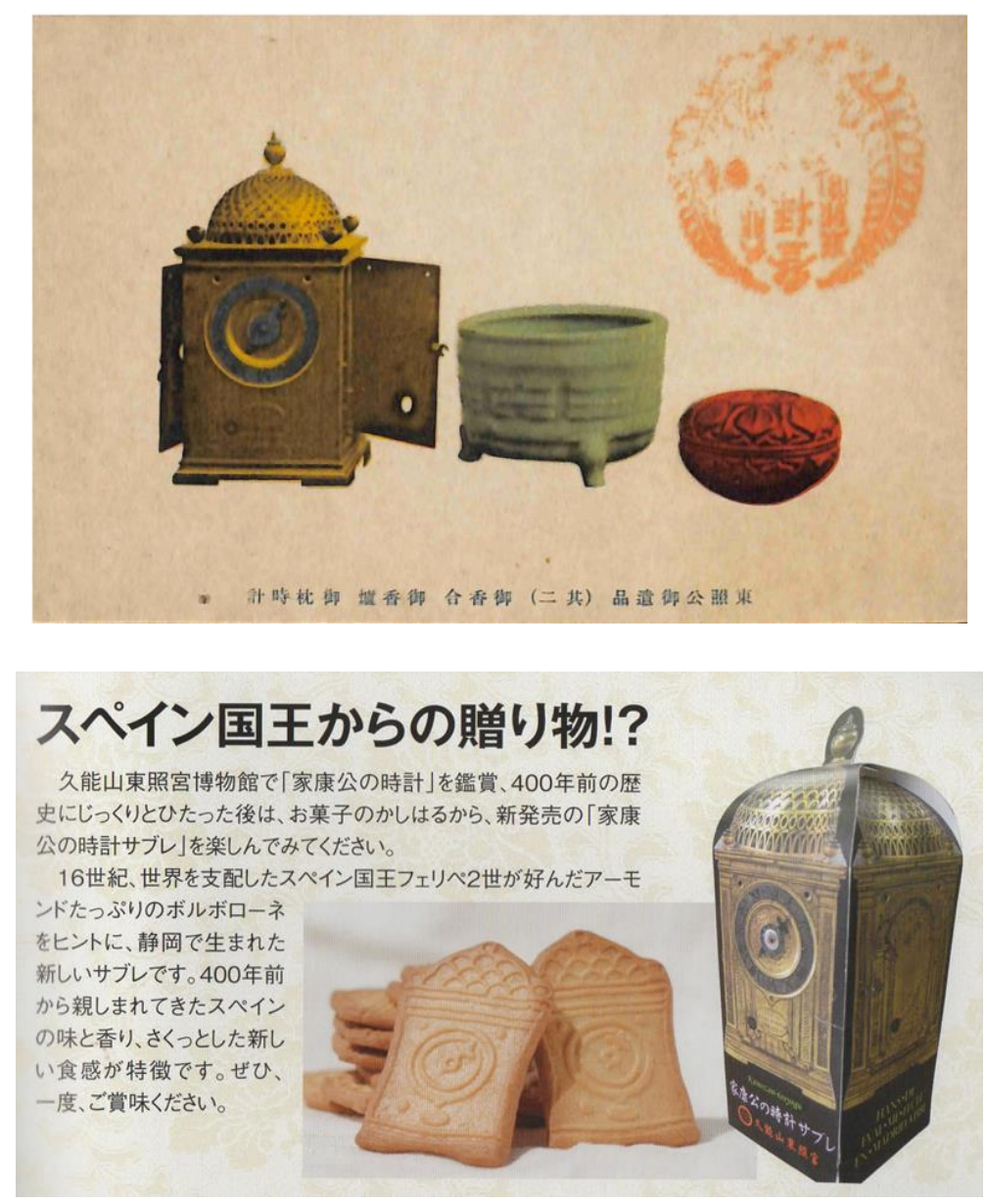

Fig. 2 Ieyasu's clock as a tourist attraction: postcard depicting Ieyasu's clock from a series on shrine treasures (top left) (Shizuoka Prefectural Library) and contemporary clock-shaped souvenir biscuits with matching packaging

As such, the clock was presented shortly before the shogunal ban on Christianity in 1614, which heralded more intense persecution and repression of the Catholic faith and the eventual expulsion of the Portuguese and Spanish from Japan. Many padres, including Giovanni Nicolao, left Japan for Malacca and Goa in the wake of Ieyasu's 1614 expulsion decree, and the Jesuit artisans' workshop ceased operations. This heralded not only the end of Jesuit clock production on Japanese soil but also an exodus of the most meticulous chroniclers of such exchanges - which certainly accounts for the disappearance of clocks from the historical record, if not necessarily from circulation, over the following decades.

Other factors may have also played their part in this. There is some evidence that mechanical clocks may have suffered an image problem due to their Christian associations as 
the government crackdown intensified. A telling comment in this context can be found in the Dutch East India Company (VOC)'s Batavia Dagh-register from 1640, soon after the Christian-led Shimabara rebellion that brought the last chapter of the Southern Barbarian presence in Japan to a close. The entry recommends turning down a Japanese order for a clock "as there are concerns that ill-meaning people would decry this as having Christian overtones," whereas no such scruples are applied to the import of the candlesticks, mortar cannons, and harnesses mentioned in the same shipment. ${ }^{87}$ Given that anti-foreign factions (the "ill-meaning people") in Japan were advocating the extension of the expulsion decree to the Dutch at that time, ${ }^{88}$ such fears were not unfounded.

Nor were they limited to Dutch perceptions. Mechanical clocks clearly had the potential to be absorbed into virulently anti-Christian rhetoric, as illustrated by an anonymous Japanese anti-Christian tract which rages against Catholic priests who bewitch the population with their "evil arts" and "wizardry" (majutsu) that included "setting up clocks which automatically strike the hours with a little bell and announce the time of day." 89 Mechanical clocks were brought to Japan by missionaries, produced by them and their converts, and were used in churches - so it was perhaps inevitable that a certain aura of Christianity clung to them. In this respect, it is no coincidence that the earliest known Japanese usage of the term “clockmaker" appears in a document dealing with Japanese Christians. ${ }^{90}$ Nevertheless, it is also clear that foreign clocks were at the same time perceived as more than ecclesiastic

\footnotetext{
${ }^{87}$ Dagh-register gehouden int casteel Batavia vant passerende daer ter plaetse als over geheel NederlandtsIndia (Batavia: Bataviaasch Genootschap van Kunsten en Wetenschappen, 1887-1931), 1640-41, 141 "Belangende de geëyschte clock hadden hun nader bedacht ende raetsaem gevonden deselve te excuseren, uyt vrese, dat eenige quaetwillige daer qualyck (als naer 't Ghristendom smakende) van mochten spreken."

${ }^{88}$ Grant K. Goodman, Japan and the Dutch, 1600-1853 (Richmond: Curzon, 2000), 15-16.

${ }^{89}$ It should be noted, however, that this was not one of the common charges levelled at Christians in such tracts, which generally spread malignant rumours about priests and their followers, and I have not been able to identify other instances. The cited passage comes from Anonymous, Yaso seibatsuki (undated manuscript, Imperial Household Agency Archives), $1 \mathrm{r}-\mathrm{v}$. The text exists in several manuscript variants and Anesaki believes it to have been originally produced in Edo in the late 1640s; see Anesaki Masaharu, Kirishitan dendō no kōhai. (Tōkyō: Dōbunkan, 1930), 809. On anti-Christian tracts and discourse in the seventeenth century more generally, see also Kiri Paramore, Ideology and Christianity in Japan (London: Routledge, 2009), Ch. 3.

${ }^{90}$ See fn. 73 above.
} 
paraphernalia: demand for them continued as illustrated by the order placed by a Japanese customer in the 1640 Batavia Dagh-register cited above. More than that, a mere five years after the warning about clock imports, the VOC presented such devices as tribute to the shogun himself.

\section{Conclusion}

If we return to our initial question of how clocks and timepieces were perceived in Ieyasu's time, it is clear that they assumed a multiplicity of meanings for various actors: they were a diplomatic tool, a demonstration of European technological prowess for foreign missionaries, an expression of power and authority on the part of their elite owners, and a source of delight and novel entertainment to the Japanese - but rarely were they mentioned specifically as instruments of time measurement, particularly in the case of mechanical clocks. This is a striking illustration of why the history of time should not simply be identified with a history of clocks, nor conversely the history of clocks with a history of time, as such an equation fails to capture the rich spectrum of meaning that contemporaries attached to these objects.

Not all of the different "regimes of value" that made these clocks desirable as commodities were able to coexist in harmony; as in the case of Ieyasu's clock, the European desire for dominance by design, for example, could easily clash with the recipient's wish to make a display of power, and such clashes of intent could lead to a breakdown in relations. Viewed in this way, clocks can be read as a node of relations, both successful and unsuccessful, at a time when Japan was first encountering the nations of Europe - and also, as we have seen in this paper, as an expression of social hierarchies and bonds within Japan itself. This politics of value surrounding early timepieces and the tug-of-war between the various meanings ascribed to them by different actors may ultimately also help us appreciate 
the mentality and the historical moment that shaped the technological transfer of clocks. Why did these exchanges not lead to Japan adopting a European-style system of equal hours? And why did the introduction of clockwork in Japan follow such a different trajectory than in Europe? Without doubt there are numerous reasons - not the least of which that the Japanese had an indigenous system of time reckoning in place that efficiently met their needs for social coordination; yet what the exchanges discussed in this paper specifically suggest is the power imbalances involved in many of these exchanges, in which clocks appear as novel and diverting tributary gifts from foreigners to the all-powerful rulers of Japan aimed at appeasing and pleasing those in authority. Unlike Japan's encounter with modernity and Western powers that led to the adoption of a the Western-style calendrical system in the nineteenth century, the "Southern Barbarians" were not bringers of enlightened civilization, but rather of exotic trade and often unsavoury Christian ideas at the mercy of Japanese rulers. While the Japanese were fascinated by the novel technology of these timepieces, they often viewed them separately from their time-telling function and in the absence of a colonizing force unsurprisingly did not appear to consider the Western-style time system to be inherently superior to their own system of variable hours.

Lastly, we should note that even though this period of Iberian contact has become synonymous with the introduction of mechanical clocks, now embodied by "Ieyasu's clock" as its one remaining survivor, it was in fact characterised by an influx of a wide range of foreign timepieces. These included non-mechanical devices, as well as a large variety of European-style mechanical clocks that reached the archipelago from abroad or were created in Japan by the Jesuits. Such mechanical timepieces went beyond the familiar weight-driven lantern clocks that served as models for the earliest Japanese-style devices: clocks with an alarm function, spring-driven clocks, astronomical clocks with a calendrical function, the first clock-watches to be worn on a string around the neck, and travel clocks with a leather case, 
such as Ieyasu's now famous piece. In this way, "Ieyasu's clock" is merely the last tangible remnant of an original plurality of clocks and the exchanges that are inextricably associated with them.

\section{REFERENCES}

\section{Pre-1900 Materials}

Anonymous. Yaso seibatsuki 耶蘇征伐記. Manuscript in the Imperial Household Agency Archives, n.d.

Archivio corrispondenza Gonzaga 1563-1630. Online database http://banchedatigonzaga.centropalazzote.it

Archivo General de Indias (AGI). Accessed online via http://pares.mcu.es/

Cartas que os padres e irmãos da Companhia de Iesus escreuerão dos Reynos de Iapão \& China aos da mesma Companhia da India, \& Europa des do anno de 1549 até o de 1580. Evora: Manoel de Lyra, 1598.

Cocks, Richard. Diary of Richard Cocks, Cape-merchant in the English Factory in Japan 1615-1622, with Correspondence. Edited by Edward Maunde Thompson. London: Hakluyt Society, 1883.

Commelin, Isaac. Begin ende Voortgangh der Vereenighde Nederlantsche Geoctroyeerde Oost-indische Compagnie. Volume 2. Place and publisher unknown, 1646.

Crasset, Jean. Histoire de l'Église du Japon. Paris: François Montalant, 1715.

Dagh-register gehouden int casteel Batavia vant passerende daer ter plaetse als over geheel Nederlandts-India. Batavia: Bataviaasch Genootschap van Kunsten en Wetenschappen, 1887-1931

Fukada Masatsugu 深田正韶. Owarishi 尾張志. Tōkyō: Hakubunsha, 1898 [1844].

Gualtieri, Guido. Relationi della venuta degli ambasciatori giaponesi. Rome: Francesco Zannetti, 1586.

Guerreiro, Fernão. Relaçam annal das cousas que fezeram os padres da Companhia de Iesus nas partes da India Oriental, \& no Brasil, Angola, Cabo Verde, Guine, nos annos de seiscentos \& dous \& sescentos \& tres. Lisbon: Jorge Rodrigues, 1605.

Guerreiro, Fernão. Relaçam annal das cousas que fizeram os padres da Companhia de Iesus nas partes da India Oriental, \& em alguas outras da conquista deste reyno no anno de 607. \& 608. Lisbon: Pedro Crasbeeck, 1611.

Lettera del Giappone de gli anni 1591 et 1592. Milano: Stampa del quon. Pacifico Pontio, 1595. 
Lucena, Juan de. Historia da vida do padre Francisco de Xavier. Lisbon: Pedro Crasbeeck, 1600.

Pasio, Francesco. Lettera annua di Giappone scritta nel 1601. Rome: Luigi Zannetti, 1603.

Piñeyro, Luys. Relacion del successo que tuvo nuestra santa fe en los Reynos del Iapon. Madrid: Alonso Martina de Balboa, 1617.

San Roman, Antonio de. Historia General de la India oriental. Valladolid: Luis Sanchez, 1603.

Solier, François. Histoire ecclésiastique des isles et royaumes du Japon. Paris: Sebastien Cramoisy, 1627.

\section{Other}

Adas, Michael. Dominance by Design: Technological Imperatives and America's Civilizing Mission. Cambridge, Mass. and London: Belknap Press of Harvard University Press, 2006.

Anesaki Masaharu 姉崎正治. Kirishitan dendō no kōhai 切支丹傳道の興廢. Tōkyō: Dōbunkan, 1930.

Appadurai, Arjun. "Introduction: Commodities and the Politics of Value", in The Social Life of Things: Commodities in Cultural Perspective, ed. Arjun Appadurai, 3-63. Cambridge: Cambridge University Press, 1986.

Bedini, Silvio A. The Trail of Time. Time Measurement with Incense in East Asia. Cambridge: Cambridge University Press, 1994.

Berry, Mary Elizabeth. Hideyoshi. Cambridge, Mass.: Harvard University Press, 1982.

Boxer, Charles R. The Christian Century in Japan, 1549-1650. Berkeley: University of California Press, 1951.

Butler, Lee. "Gifts for the Emperor: Signposts of Continuity and Change in Japan's Fifteenth and Sixteenth Centuries." In Mediated by Gifts. Politics and Society in Japan, 1350-1850, ed. Martha Chaiklin, 48-81. Leiden: Brill, 2017.

Chaiklin, Martha. Cultural Commerce and Dutch Commercial Culture: The Influence of European Material Culture on Japan, 1700-1850. Leiden: Research School CNWS Leiden University, 2003.

Cooper, Michael. This Island of Japon: Joao Rodrigues' Account of Sixteenth Century Japan. Tokyo: Kodansha International, 1973.

Cooper, Michael. The Japanese Mission to Europe, 1582-1590: The Journey of Four Samurai Boys through Portugal, Spain and Italy. Folkestone: Global Oriental, 2005. 
Cooper, Michael. An Unscheduled Visit: Rodrigo de Vivero in Japan, 1609-1610. Tokyo: Asiatic Society of Japan, 2008.

Dohrn-van Rossum, Gerhard. History of the Hour: Clocks and Modern Temporal Orders. Chicago: University of Chicago Press, 1996.

Dohrn-van Rossum, Gerhard. "Time." In The Oxford Handbook of Early Modern European History, 1350-1750. Volume 1: People and Places, ed. Hamish Scott, 145-164. Oxford: Oxford University Press, 2015.

Elison, George. Deus Destroyed: The Image of Christianity in Early Modern Japan. Cambridge, Mass.: Harvard University Council on East Asian Studies, 1988.

Farré Olivé, Eduard. "Vuelve a España el reloj de Hans de Evalo." Galería Antiquria 26, no. 276 (2008): 34-40.

Farrington, Anthony. The English Factory in Japan, 1613-1623. London: British Library, 1991.

Fraiture, Eddy and Paul van Rompay. "Clock and Watchmaking in Belgium, 1300-1830." Antiquarian Horology 33, no. 1 (2011): 27-45.

Frumer, Yulia. Making Time: Astronomical Time Measurement in Tokugawa Japan. Chicago: University of Chicago Press, 2018.

García Gutiérrez, Fernando. "Giovanni Cola S. J. (Nicolao). Un hombre del Renacimiento italiano trasplantado a Japón.” Temas de estética y arte 25 (2011): 96-124.

Gil, Juan. Hidalgos y samurais: España y Japón en los siglos XVI y XVII. Madrid: Alianza Editorial, 1991.

Goodman, Grant K. Japan and the Dutch, 1600-1853. Richmond: Curzon, 2000.

Gunn, Geoffrey C. First Globalization: The Eurasian Exchange, 1500 to 1800. Lanham, Md.: Rowman \& Littlefield, 2003.

Haboush, JaHyun Kim and Kenneth R. Robinson. A Korean War Captive in Japan, 15971600: The Writings of Kang Hang. New York: Columbia University Press, 2013.

Hall, John Whitney, Nagahara Keiji, and Yamamura Kozo, eds. Japan before Tokugawa: Political Consolidation and Economic Growth, 1500-1650. Princeton: Princeton University Press, 1987.

Hashimoto Manpei 橋本万平. Nihon no jikoku seidō 日本の時刻制度. Tōkyō: Hanawa Shobō, 2002 [1966].

Hashimoto, Takehiko. "Japanese Clocks and the History of Punctuality in Modern Japan." East Asian Science, Technology and Society 2, nr. 1 (2008): 123-133. https://doi.org/10.1215/s12280-008-9031-z 
Hesselink, Reinier. The Dream of Christian Nagasaki: World Trade and the Clash of Cultures. Jefferson: McFarland \& Company, 2016.

Kawamoto Nobuo 河本信雄. “Nihon de no kikai tokei seisaku kaishi jiki no kōsatsu 日本で の機械時計開始時期の考察.” Wadokei 和時計 47 (2015): 1-19.

Koch, Angelika. "Nightless Cities: Timing the Pleasure Quarters in Early Modern Japan." Kronoscope 17, no. 1 (2017): 61-93. https://doi.org/10.1163/15685241-12341370

Kokushi Taikei Kankōkai 国史大系刊行会, eds. Kokushi taikei 国史大系 40. Tōkyō: Yoshikawa Kōbunkan, 1930.

Kokusho Kankōkai 国書刊行会, eds. Tsūkō ichiran 通航一覧. Tōkyō: Kokusho Kankōkai, 1912.

Kondō Katsuyuki 近藤勝之. “Edo tokei nenpyō kaiteiban 江戸時計年表改訂版.” Wadokei 和時計 47 (2015): 30-35.

Lach, Donald F. Asia in the Making of Europe, Volume I, Book 2. Chicago: University of Chicago Press, 1965.

Lamers, Jeroen P. Japonius Tyrannus: The Japanese Warlord Oda Nobunaga Reconsidered. Leiden: Hotei, 2000.

Latour, Bruno. Reassembling the Social: An Introduction to Actor-network-theory. Oxford: Clarendon, 2005.

Massarella, Derek, ed. Japanese Travellers in Sixteenth-century Europe: A Dialogue concerning the Mission of the Japanese Ambassadors to the Roman Curia (1590). With a translation by J.F. Moran. Farnham: Ashgate/Hakluyt Society, 2012.

Matsuda Kiichi 松田毅一, ed. Jūroku-shichi-seiki Iezusukai Nihon hōkokushū 十六・七世紀 イエズス会日本報告集. Kyōto-shi: Dōhōsha Shuppan, 1987-.

Maurice, Klaus. "Propogatio fidei per scientias: Jesuit Gifts to the Chinese Court," in The Clockwork Universe: German Clocks and Automata, 1550-1650, eds. Klaus Maurice and Otto Mayr, 27-36. Washington D.C.: Smithsonian, 1980.

Mori Takeshi 森威史. Ieyasu no tokei toraiki 家康の時計渡来記. Shizuoka: Hagoromo Shuppan, 2017.

Mraz, Gottfried. "The Role of Clocks in the Imperial Honoraria for the Turks," in The Clockwork Universe: German Clocks and Automata, 1550-1650, eds. Klaus Maurice and Otto Mayr, 37-48. Washington D.C.: Smithsonian, 1980.

Murakami Naojirō 村上直次郎, ed. Ikoku ōfuku shokanshū. Zōtei ikoku nikkishō 異國往復 書翰集増訂・異國日記抄. Tōkyō: Sunnansha, 1929. 
Needham, Joseph. Science and Civilisation in China, Vol. 3. Mathematics and the Sciences of the Heavens and the Earth. Cambridge: Cambridge University Press, 1959.

Needham, Joseph, Wang Ling and Derek J. Price. Heavenly Clockwork: The Great Astronomical Clocks of Medieval China. Cambridge: Cambridge University Press, 1986.

Ochiai Hidekuni 落合偉洲. Ieyasu-kō no tokei: Yonhyakunen o koeta kiseki 家康公の時計: 四百年を超えた奇跡. Tōkyō: Heibonsha, 2013.

Pagani, Catherine. Eastern Magnificence \& European Ingenuity: Clocks of Late Imperial China. Ann Arbor: University of Michigan Press, 2001.

Paramore, Kiri. Ideology and Christianity in Japan. London: Routledge, 2009.

Pitelka, Morgan. Spectacular Accumulation: Material Culture, Tokugawa Ieyasu, and Samurai Sociability. Honolulu: University of Hawaii Press, 2016.

Reff, Daniel T., Richard K. Danford, and Robin Gill, eds. The First European Description of Japan, 1585: A Critical English-language Edition of Striking Contrasts in the Customs of Europe and Japan by Luis Frois. London: Routledge, 2014.

Sánchez Cantón, F. J., ed. Inventarios reales. Bienes muebles que pertenecieron a Felipe II. Madrid: Real Academia de la Historia, 1956-1959.

Sasaki Katsuhiro 佐々木 勝浩 and Saitō Yō 齋藤 曜. “Kunōzan Tōshōgū ni hozon sarete iru 1581-nen Hansu de Ebaro-mei okidokei no kikō to yurai 久能山東照宮に保存されて いる 1581 年ハンス・デ・エバロ銘置時計の機構と由来.” Bulletin of the National Museum of Nature and Science, Series E, no. 39 (2016): 1-26.

Sawada Taira 沢田平. Wadokei: Edo no haiteku gijutsu 和時計 : 江戶のハイテク技術 (Kyōto: Tankōsha, 1996).

Schuster, Ingrid. Faszination Ostasien. Zur kulturellen Interaktion Europa--Japan--China: Aufsätze aus drei Jahrzehnten. Bern, Oxford: Peter Lang, 2007.

Schurhammer, Georg. Francis Xavier: His Life, His Times. Vol.4. Rome: Jesuit Historiographical Institute, 1982.

Schurhammer, Georg and Josef Wicki. Epistolae S. Francisci Xaverii Aliaque Eius Scripta. Rome: Monumenta Historica Societatis Iesu, 1944.

Schütte, Josef Franz. Valignanos Missionsgrundsätze für Japan. Roma: Edizioni Di Storia E Letterature, 1951.

Screech, Timon. The Lens within the Heart. The Western Scientific Gaze and Popular Imagery in Later Edo Japan. Honolulu: University of Hawaii Press, 2002.

Screech, Timon. Edo no Igirisu netsu: Rondon bashi to Rondon dokei 江戸の英吉利熱 : ロ ンドン橋とロンドン時計. Tōkyō: Kōdansha, 2006. 
Tamon, Miki. "The Influence of Western Culture on Japanese Art," Monumenta Nipponica 19, no. 3/4 (1964): 380-401.

ten Hoeve, Johan and David Thompson. "A Flemish Clock at the Shogun's Shrine." Antiquarian Horology 35, no. 4 (2014): 1063-1076.

Toby, Ronald. State and Diplomacy in Early Modern Japan: Asia in the Development of the Tokugawa Bakufu. Princeton: Princeton University Press, 1984.

Toby, Ronald. Engaging the Other. "Japan” and its Alter Egos, 1550-1850. Leiden: Brill, 2019.

(Tōkyō Teikoku Daigaku Bungaku-bu) Shiryō Hensangakari 史料編纂掛, eds. Dai Nihon shiryō 大日本史料. Tōkyō: Teikoku Daigaku, 1901-.

Totman, Conrad. Tokugawa Ieyasu: Shogun. San Francisco: Heian, 1983.

Venturi, Pietro Tacchi. Opere Storiche del P. Matteo Ricci, S.I. Macerata: Premiato Stab. Tip.

F. Giorgetti, 1911.

Vlam, Grace. "Kings and Heroes: Western-Style Painting in Momoyama Japan." Artibus Asiae 39, no.3/4 (1977): 220-250. doi:10.2307/3250166.

Yamaguchi Ryūji 山口隆二. Nihon no tokei: Tokugawa jidai no wadokei no kenkyū 日本の 時計: 徳川時代の和時計の研究. Tōkyō: Nihon Hyōronsha, 1950 [1942].

Zanetti, Cristiano. Janello Torriani and the Spanish Empire: A Vitruvian Artisan at the Dawn of the Scientific Revolution. Leiden: Brill, 2017.

Zoku Gunsho Ruijū Kanseikai 続群書類従完成会, eds. Gunsho Ruijū 群書類従. Tōkyō: Zoku Gunsho Ruijū Kanseikai, 1957.

APPENDIX: CHRONOLOGICAL OVERVIEW

\begin{tabular}{|c|c|c|c|c|}
\hline Date & Event & Clock Type & Source & Origin \\
\hline 1551 & $\begin{array}{l}\text { Francis Xavier presents } \\
\text { Öuchi Yoshitaka, the } \\
\text { daimyo of Suō } \\
\text { Province, with a } \\
\text { mechanical clock }\end{array}$ & $\begin{array}{l}\text { clock (de Torres), a } \\
\text { small striking clock } \\
\text { (Crasset), a wheel } \\
\text { clock (Lucena), one } \\
\text { of these small } \\
\text { German clocks (San } \\
\text { Roman) }\end{array}$ & $\begin{array}{l}\text { Letters by Cosme } \\
\text { de Torres } \\
\text { (Cartas) and } \\
\text { Francis Xavier of } \\
\text { 1551/1552; } \\
\text { Yoshitakaki }\end{array}$ & $\begin{array}{l}\text { Germany(?) } \\
\text { via } \\
\text { Malacca } \\
\text { (gift from } \\
\text { the Captain } \\
\text { of Melacca) }\end{array}$ \\
\hline 1569 & \begin{tabular}{ll}
\multicolumn{2}{c}{ Timepieces mentioned } \\
as gifts to Oda \\
Nobunaga
\end{tabular} & $\begin{array}{ll}\text { sundials } & \text { and } \\
\text { hourglasses } & \end{array}$ & $\begin{array}{l}\text { Frois' letter dated } \\
1 \text { June } 1569 \\
\text { (Cartas); Frois } \\
\text { Historia }\end{array}$ & $\begin{array}{l}\text { Unspecified } \\
\text { European }\end{array}$ \\
\hline
\end{tabular}




\begin{tabular}{|c|c|c|c|c|}
\hline 1569 & $\begin{array}{l}\text { Luis } \\
\text { demonstrates an alarm } \\
\text { clock to Oda Nobunaga } \\
\text { and shogun Ashikaga } \\
\text { Yoshiaki on two } \\
\text { separate occasions; the } \\
\text { shogun sends for } \\
\text { another, reportedly } \\
\text { even more marvellous } \\
\text { clock, from Bungo }\end{array}$ & alarm clock & $\begin{array}{l}\text { Frois' letter dated } \\
1 \text { June } 1569 \\
\text { (Cartas); Frois } \\
\text { Historia }\end{array}$ & \\
\hline 1569 & $\begin{array}{l}\text { Luis Frois presents Oda } \\
\text { Nobunaga with an } \\
\text { hourglass to thank him } \\
\text { for permission to } \\
\text { preach in Kyoto }\end{array}$ & hourglass & $\begin{array}{l}\text { Frois' letter dated } \\
\text { 1 June } 1569 \\
\text { (Cartas) }\end{array}$ & \\
\hline 1581 & $\begin{array}{l}\text { Oda Nobunaga visits } \\
\text { the Jesuit residence at } \\
\text { Azuchiyama and is } \\
\text { shown a clock and } \\
\text { other curiosities }\end{array}$ & & $\begin{array}{l}\text { Gaspar Coelho's } \\
\text { annual letter } \\
\text { dated February } \\
\text { 1582 (Cartas II, } \\
41)\end{array}$ & \\
\hline 1585 & \multicolumn{4}{|c|}{$\begin{array}{l}\text { Frois mentions Japan's hour system and methods of time measurement in his } \\
\text { Treatise on Striking Contrasts }\end{array}$} \\
\hline 1591 & $\begin{array}{l}\text { The Tenshō Mission to } \\
\text { Europe organised by } \\
\text { Alessandro Valignano } \\
\text { presents Toyotomi } \\
\text { Hideyoshi with a clock } \\
\text { and returns with } \\
\text { several timepieces; } \\
\text { these and other objects } \\
\text { including a world map } \\
\text { attract attention from } \\
\text { Japanese lords en route } \\
\text { to Kyoto }\end{array}$ & $\begin{array}{l}\text { striking clocks, a } \\
\text { striking } \text { watch } \\
\text { (Crasset); four small } \\
\text { striking clocks for } \\
\text { wearing around the } \\
\text { neck (Gualtieri) }\end{array}$ & $\begin{array}{l}\text { Documents in the } \\
\text { Gonzaga archives } \\
\text { dated June 1585; } \\
\text { Gualtieri; } \\
\text { Valignano's letter } \\
\text { to Teotonio of } \\
\text { Braganza dated } 1 \\
\text { December } 1587 \\
\text { (Cartas); Frois' } \\
\text { annual letter of } \\
\text { 1592; Crasset; } \\
\text { Solier }\end{array}$ & $\begin{array}{l}\text { Italy (gifts } \\
\text { from the } \\
\text { Duke of } \\
\begin{array}{l}\text { Mantua in } \\
1585)\end{array} \\
\& \\
\text { Portugal } \\
\text { (gift from } \\
\text { Theotonio } \\
\text { de } \\
\text { Braganza, } \\
\text { Archbishop } \\
\text { of Evora) }\end{array}$ \\
\hline $\begin{array}{l}\text { Ca. } \\
1607- \\
1616 ?^{91}\end{array}$ & $\begin{array}{l}\text { Tsuda Sukuzaemon } \\
\text { repairs a Korean clock } \\
\text { and makes a new clock } \\
\text { for Tokugawa Ieyasu }\end{array}$ & Korean clock & Owarishi & \\
\hline $\begin{array}{l}\text { Ca. } \\
1600\end{array}$ & $\begin{array}{l}\text { A Jesuit priest } \\
\text { (Giovanni Nicolao) } \\
\text { produces clocks, } \\
\text { organs and Western- } \\
\text { style paintings at the }\end{array}$ & $\begin{array}{l}\text { many wheel clocks } \\
\text { for our usage } \\
\text { (Pasio); many } \\
\text { clocks, among them } \\
\text { very curious ones }\end{array}$ & $\begin{array}{lr}\text { Francisco } & \text { Pasio's } \\
\text { annual } & \text { letter, } \\
\text { 1601; Guerreiro, } \\
\text { Solier }\end{array}$ & \\
\hline
\end{tabular}

\footnotetext{
${ }^{91}$ Traditionally Japanese scholarship has placed this event much earlier (around 1598), but as Kawamoto has convincingly argued, this dating is unlikely. See Kawamoto, "Nihon de no kikai tokei seisaku."
} 


\begin{tabular}{|c|c|c|c|c|}
\hline & $\begin{array}{l}\text { Jesuit workshop in } \\
\text { Arima }^{92}\end{array}$ & $\begin{array}{l}\text { that mark the course } \\
\text { of the sun and moon } \\
\text { (Guerreiro and } \\
\text { Solier) }\end{array}$ & & \\
\hline $\begin{array}{l}\text { Ca. } \\
1600- \\
1615\end{array}$ & $\begin{array}{l}\text { Japanese nanban } \\
\text { screen depicts an } \\
\text { astronomical clock in a } \\
\text { European court setting }\end{array}$ & $\begin{array}{l}\text { weight-driven, } \\
\text { astronomical wall } \\
\text { clock with European } \\
\text { hour markings (1- } \\
\text { 12) that indicates the } \\
\text { position of the sun } \\
\text { and moon }\end{array}$ & $\begin{array}{l}\text { European King } \\
\text { and Members of } \\
\text { His Court, six- } \\
\text { panel folding } \\
\text { screen (Museum } \\
\text { of Fine Arts } \\
\text { Boston) }\end{array}$ & \\
\hline $1605 / 06$ & $\begin{array}{l}\text { Jesuit missionary Joao } \\
\text { Rodriguez presents } \\
\text { Tokugawa Ieyasu with } \\
\text { a clock at Fushimi } \\
\text { Castle }\end{array}$ & $\begin{array}{l}\text { a clock presented on } \\
\text { behalf of the Father } \\
\text { Provincial [...] that } \\
\text { showed the course of } \\
\text { the sun and moon } \\
\text { and signalled the } \\
\text { days (Guerreiro); a } \\
\text { striking clock that } \\
\text { marked the course of } \\
\text { the sun and moon } \\
\text { (Solier and Crasset) }\end{array}$ & $\begin{array}{l}\text { Guerreiro, Solier, } \\
\text { Crasset }\end{array}$ & \\
\hline 1607 & $\begin{array}{l}\text { The shogun Hidetada } \\
\text { asks a Japanese Jesuit } \\
\text { to help him install a } \\
\text { clock he had ordered } \\
\text { from Nagasaki }\end{array}$ & $\begin{array}{l}\text { a striking clock to } \\
\text { announce the hours } \\
\text { that the shogun had } \\
\text { ordered from the } \\
\text { Jesuits in Nagasaki } \\
\text { (Guerreiro, Solier, } \\
\text { Crasset) }\end{array}$ & $\begin{array}{l}\text { Guerreiro, Solier, } \\
\text { Crasset }\end{array}$ & Nagasaki \\
\hline 1611 & 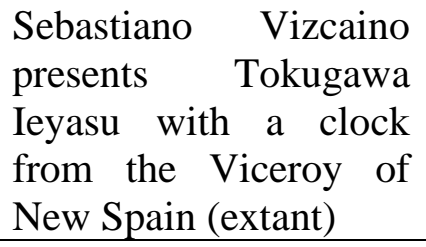 & $\begin{array}{l}\text { spring-driven } \\
\text { mechanical table } \\
\text { clock in a leather } \\
\text { travel case }\end{array}$ & $\begin{array}{l}\text { Ikoku nikki, } \\
\text { Tokugawa jikki }\end{array}$ & \\
\hline 1611 & $\begin{array}{l}\text { Dutch (Jacob Specx } \\
\text { and Pieter Siergertsz) } \\
\text { present the shogun with } \\
\text { a clock }\end{array}$ & a golden clock & $\begin{array}{l}\text { Journals of the } \\
\text { Verhoeven } \\
\text { expedition in } \\
\text { Commelin's } \\
\text { Begin ende } \\
\text { voortgang vande } \\
\text { Vereenigde } \\
\text { Neederlantsche } \\
\text { Geoctroyeerde } \\
\text { Oost-Indische } \\
\text { Compagnie }\end{array}$ & \\
\hline
\end{tabular}

\footnotetext{
${ }^{92}$ Pasio locates these activities in Arima; Solier contains an almost identical statement, but gives Nagasaki as the location. This is likely due to the fact that the Jesuit artisans' workshop moved several times in 1601/1602, see Tamon Miki, "The Influence of Western Culture on Japanese Art," Monumenta Nipponica 19, no. 3/4 (1964): 148-150.
} 


\begin{tabular}{|c|c|c|c|c|}
\hline 1614 & $\begin{array}{l}\text { Tokugawa } \\
\text { orders } \\
\text { Masatake to present a } \\
\text { clock to the shogunate }\end{array}$ & $\begin{array}{l}\text { clock without } \\
\text { weights (i.e. } \text { spring- } \\
\text { driven?) }\end{array}$ & $\begin{array}{l}\text { Sunpu nikki, } \\
\text { Tokugawa jikki }\end{array}$ & \\
\hline 1615 & \multicolumn{4}{|c|}{$\begin{array}{l}\text { Richard Cocks records giving "two ivory sundials, compass-like" to a "China } \\
\text { captain" and having his clock repaired (possibly in Nagasaki) }\end{array}$} \\
\hline $\begin{array}{l}1617- \\
18\end{array}$ & $\begin{array}{l}\text { Ieyasu's assets after his } \\
\text { death include sundials, } \\
\text { sand clocks and likely } \\
\text { mechanical clocks }\end{array}$ & $\begin{array}{l}\text { a square clock, a } \\
\text { Chinese clock, } \\
\text { sundials, sand clocks }\end{array}$ & $\begin{array}{ll}\text { Sunpu } & o- \\
\text { wakemono } & o- \\
\text { dōgu chō } & \end{array}$ & \\
\hline $\begin{array}{l}\text { ca. } \\
1613\end{array}$ & \multicolumn{4}{|c|}{$\begin{array}{l}\text { The Franciscan friar Alonso Muñoz lists "watches to be worn on the chest" } \\
\text { (relojes de pecho) as suitable presents for the shogun in a memorandum to the } \\
\text { Spanish court (undated Memorandum of things that His Majesty could send to the } \\
\text { Emperor of Japan and his son the prince, which are esteemed in these parts } \\
\text { because they do not have them there) }\end{array}$} \\
\hline 1640 & $\begin{array}{l}\text { VOC records } \\
\text { recommend halting } \\
\text { clock imports to Japan } \\
\text { because of their } \\
\text { Christian overtones }\end{array}$ & $\begin{array}{l}\text { a hanging clock } \\
\text { (ordered by an } \\
\text { unknown person in } \\
\text { Japan) }\end{array}$ & $\begin{array}{l}\text { Batavia's } \\
\text { uitgaand } \\
\text { brievenboek }\end{array}$ & \\
\hline 1643 & \multicolumn{4}{|c|}{$\begin{array}{l}\text { Tokugawa jikki mentions the existence of a 'clock room' (tokei no ma) in Edo } \\
\text { Castle }\end{array}$} \\
\hline 1645 & $\begin{array}{l}\text { VOC presents a clock } \\
\text { to the shogun } \\
\text { Tokugawa Iemitsu }\end{array}$ & & Tokugawa jikki & \\
\hline 1647 & $\begin{array}{l}\text { VOC presents pocket } \\
\text { watches to Iemitsu and } \\
\text { his heir }\end{array}$ & pocket watches & Tokugawa jikki & \\
\hline
\end{tabular}

Table 1: Japanese Encounters with European-Style Timepieces

NB: This chronology is compiled based on the printed versions of Jesuit correspondence and other printed reports that circulated in the sixteenth and seventeenth centuries, rather than the original Jesuit manuscript letters, which were often edited and revised before publication.

\footnotetext{
${ }^{93}$ Included in AGI FILIPINAS,193, N.3.
} 